\title{
Contact-Era Chronology Building in Iroquoia: Age Estimates for Arendarhonon Sites and Implications for Identifying Champlain's Cahiagué
}

\author{
Sturt W. Manning (D, Jennifer Birch, Megan Anne Conger, Michael W. Dee, \\ Carol Griggs, and Carla S. Hadden
}

\begin{abstract}
Radiocarbon dating is rarely used in historical or contact-era North American archaeology because of idiosyncrasies of the calibration curve that result in ambiguous calendar dates for this period. We explore the potential and requirements for radiocarbon dating and Bayesian analysis to create a time frame for early contact-era sites in northeast North America independent of the assumptions and approximations involved in temporal constructs based on trade goods and other archaeological correlates. To illustrate, we use Bayesian chronological modeling to analyze radiocarbon dates on short-lived samples and a post from four Huron-Wendat Arendarhonon sites (Benson, Sopher, Ball, and Warminster) to establish an independent chronology. We find that Warminster was likely occupied in 1615-1616, and so is the most likely candidate for the site of Cahiagué visited by Samuel de Champlain in 1615-1616, versus the other main suggested alternative, Ball, which dates earlier, as do the Sopher and Benson sites. In fact, the Benson site seems likely to date 50 years earlier than currently thought. We present the methods employed to arrive at these new, independent age estimates and argue that absolute redating of historic-era sites is necessary to accurately assess existing interpretations based on relative dating and associated regional narratives.
\end{abstract}

Keywords: Iroquoian archaeology, Warminster, Ball, Sopher, Benson, radiocarbon dating, Bayesian chronological modeling, Champlain, Cahiagué

La datation par le radiocarbone est rarement utilisée dans l'archéologie de l'Amérique du Nord, historique ou de l'époque des contacts, en raison des particularités de la courbe de calibration qui donnent lieu aux dates ambiguës pour le calendrier. Nous explorons le potentiel et les exigences pour les datations radiocarbone et d'analyses Bayésienne afin de créer un calendrier pour les sites de début de la période contact dans le nord-est de l'Amérique du Nord séparent des hypothèses et approximations impliquées dans les constructions temporelles basées sur les marchandises commerciales et d'autres corrélats archéologiques. Comme démonstration, nous utilisons la modélisation chronologique Bayésienne pour analyser les dates par le radiocarbone sur des échantillons éphémères et un poteau de quatre sites Huron-Wendat Arendarhonon (Benson, Sopher, Ball et Warminster) afin d'établir une chronologie indépendante. Nous trouvons que Warminster était probablement occupé pendant 1615-1616, ce qui en fait le candidat le plus probable pour le site de Cahiagué visité par Samuel de Champlain en 1615-1616, par rapport à l'autre alternative principale suggérée, Ball, qui est plus ancien, comme les sites Sopher et Benson. En fait, le site Benson semble dater d'environ cinquante ans ( 50) plus tôt que prévu. Nous présentons les méthodes employées pour arriver à ces nouvelles estimations d'âge indépendant et affirmons qu'une re-datation absolue des sites de l'époque historique est nécessaire pour évaluer avec précision les interprétations existantes basées sur la datation relative et les récits régionaux associés.

Mots-clés: l'archéologie Iroquoise, Warminster, Ball, Sopher, Benson, Les datations radiocarbone, La modélisation chronologique Bayesienne, Champlain, Cahiagué

Sturt W. Manning — Cornell Tree Ring Laboratory, Department of Classics, Cornell University, Ithaca, NY 14853, USA (sm456@ cornell.edu, corresponding author) https://orcid.org/0000-0002-6917-0927

Jennifer Birch and Megan Anne Conger - Department of Anthropology, University of Georgia, 250 Baldwin Hall, Jackson Street, Athens, GA 30602-1619, USA

Michael W. Dee $\square$ Centre for Isotope Research, Faculty of Science and Engineering, University of Groningen, Nijenborgh 6, NL-9747 AG. Groningen, Netherlands

Carol Griggs - Cornell Tree Ring Laboratory, Department of Classics, Cornell University, Ithaca, NY 14853, USA

Carla S. Hadden $\square$ Center for Applied Isotope Studies, University of Georgia, 120 Riverbend Rd, Athens, GA 30602, USA

American Antiquity 84(4), 2019, pp. 684-707

Copyright (C) 2019 by the Society for American Archaeology. This is an Open Access article, distributed under the terms of the Creative Commons Attribution licence (http://creativecommons.org/licenses/by/4.0/), which permits unrestricted re-use, distribution, and reproduction in any medium, provided the original work is properly cited.

doi:10.1017/aaq.2019.60 
$\mathrm{U}$ ntil quite recently, radiocarbon dating has been underused to resolve questions about historical or contact-era events in North American archaeology. Because of the perceived security of dates derived from trade good assemblages (e.g., Bradley 2007; Fitzgerald 1990; Kenyon and Kenyon 1983) and a reliance on canonical telling and retelling of the ethnohistoric record (e.g., Tooker 1964; Trigger 1969, 1976), archaeologists have only recently begun to evaluate the efficacy of absolute dating techniques for linking the archaeological record to historically documented events (e.g., Manning et al. 2018; Thompson et al. 2019). One such event occurred in the summer of AD 1615 (all calendar dates in this article are AD), when Samuel de Champlain visited a village he called Cahiagué en route to assist an assembled party of Wendat (Huron) warriors in their raid against the Onondaga (Biggar 1922-1936:3:49). Champlain is a figure who looms large in the Canadian historical pantheon, and identifying the sites that he and other notable European explorers and missionaries visited during their voyages occupies a prominent place in the archaeological imagination. There has been a long-standing debate in Iroquoian archaeology about what archaeological site may represent the village of Cahiagué. The primary candidates have been the Ball and Warminster sites (e.g., Fitzgerald 1986; McIlwraith 1946, 1947; Sykes 1983; Trigger 1976; see Figure 1). Another contact-era site, Hunter's Oro 41, is a third candidate (Fitzgerald 1986); however, it is generally agreed to be too small ( 0.8 ha) and likely dates to the later Jesuit period, thus being a candidate for a small village that was reported burned down in 1642 (Trigger 1976:660-661; Warrick 2008:219, 237). For these reasons, we do not consider this site here. Until now, much of this debate has rested on historical and linguistic data, as well as relative frequencies and types of trade goods.

Although the Warminster-as-Cahiagué debate was believed to have been largely resolved by the 1990s (Fitzgerald et al. 1995), recent redating of the Warminster site leads us to suggest that critical, independent assessment of chronological assignments for sites previously dated based on trade good assemblages is warranted. When dated in isolation, and compared with a sequence of village sites located on West Duffins Creek, east of Toronto, Manning and colleagues (2018) found that Warminster was at least partly contemporary with the Jean-Baptiste Lainé (Mantle) site. This is despite vast disparities in the frequency and types of European goods occurring on each-Warminster containing hundreds of glass beads and other items of European manufacture and the full excavation of JeanBaptiste Lainé revealing only two European copper beads and an iron fragment. The two sites had previously been placed 75-100 years apart in time on the basis of these trade good assemblages (Birch and Williamson 2013; Fitzgerald et al. 1995). The present analysis is prompted by this demonstrated discrepancy between the relative (trade good-based) and absolute (radiocarbon) temporal records. Our objectives here are twofold. First, to test the assertion that the Warminster site is the most likely candidate for the village of Cahiagué using empirical evidence derived from radiocarbon dating that is independent of trade good chronologies. Second, to evaluate the applicability of employing radiocarbon dating and Bayesian analysis of radiocarbon dates to construct refined timeframes independent of, and as tests of, existing temporal constructs based on trade goods and other archaeological correlates for site sequences from the early contact era. By doing so, we aim to avoid circular reasoning, and to provide new, absolute, temporal datasets that permit the interpretation of contact-era archaeological assemblages as the remains of Indigenous action and agency vis-à-vis the reception, rejection, and negotiation of European influences in the sixteenth- and seventeenth-century Northeast.

In this article, we introduce a suite of recently analyzed AMS ${ }^{14} \mathrm{C}$ dates on short-lived botanicals from the Benson, Sopher, Ball, and Warminster sites and a preserved tamarack (Larix laricina) post associated with House 4 at Warminster (Table 1). The dates derive from four modern radiocarbon laboratories each yielding compatible results. We employ Bayesian chronological modeling (e.g., Bayliss 2009, 2015; Bronk Ramsey 2009a; Hamilton and Krus 2018; Manning et al. 2006; Whittle et al. 2011). This technique permits integration of the ${ }^{14} \mathrm{C}$ dates on the short-lived samples, the tree ring ${ }^{14} \mathrm{C}$ wiggle-match dating of the 


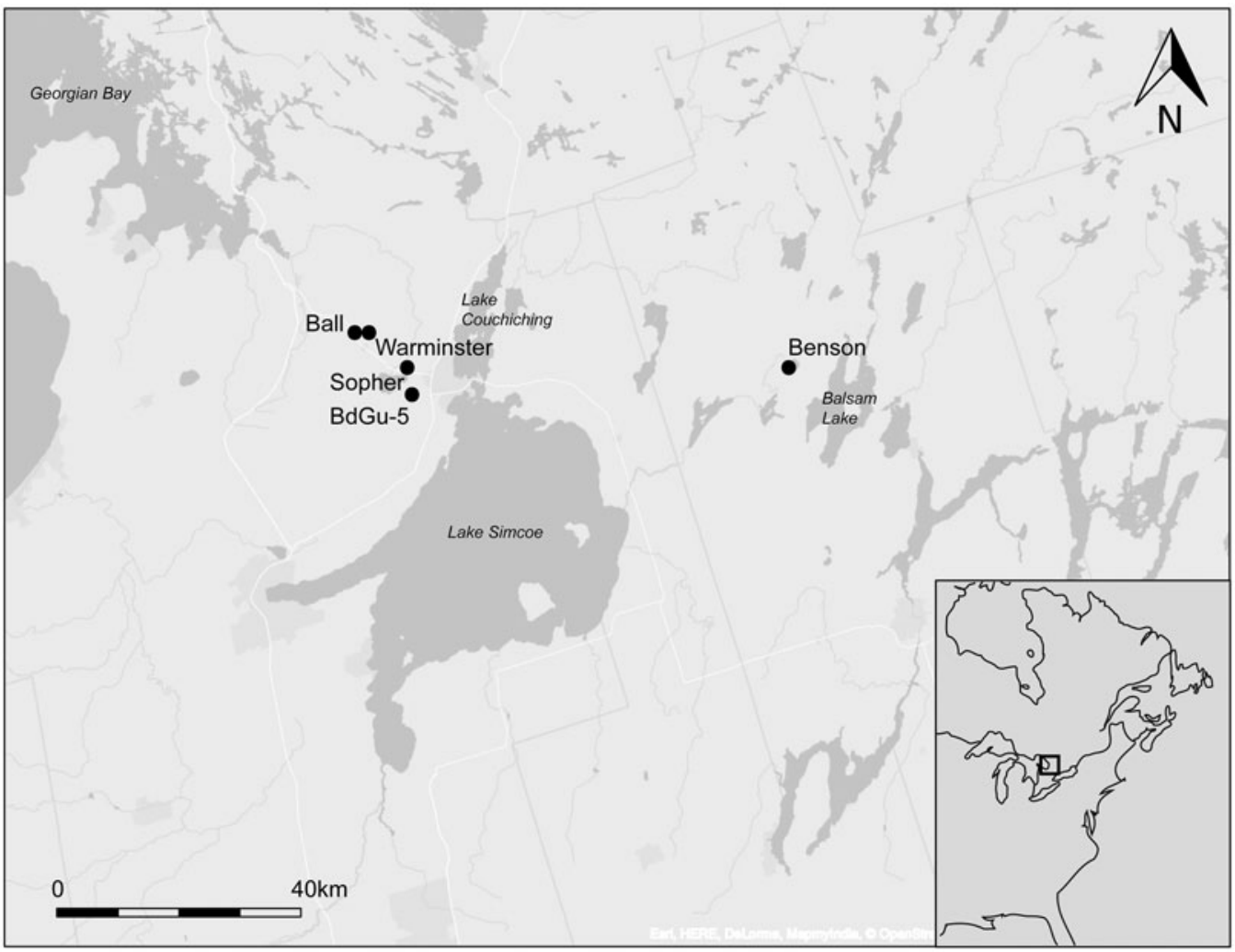

Figure 1. Regional map, including sites identified in text. Base map: ESRI.

post (e.g., Bronk Ramsey et al. 2001; Galimberti et al. 2004; Manning et al. 2018), and archaeological and ethnohistoric evidence. We can thus investigate and quantify various possible assumptions concerning the order and duration of site occupations to produce refined age estimates for the sites. Our results indicate that Warminster was occupied during 1615-1616 (see also Manning et al. 2018). In addition, both the archaeological evidence and the radiocarbon evidence (independently) suggest the following set of outcomes:

- Ball, considered the immediate predecessor village of the same community later located at the Warminster site, was earlier than Warminster.

- Sopher was perhaps earlier than the Ball site but may also have overlapped.

- Benson chronologically preceded Warminster, Ball, and Sopher and, although not necessarily in a direct site relocation sequence (but $\mathrm{cf}$.
Michelaki et al. 2013), thus sets a likely terminus post quem (TPQ) for these sites. The analysis also places the occupation of Benson somewhat earlier than previous interpretations have suggested (i.e., Ramsden 2016a, 2016b).

This set of findings provides independent evidence for the assertion that Warminster is most likely the village of Cahiagué visited by Champlain. It also confirms that $\mathrm{AMS}{ }^{14} \mathrm{C}$ dating of short-lived botanicals and tree rings combined with Bayesian modeling can achieve results that permit the precise pinpointing of historical events in the archaeological record, suggesting that further work of this nature is both achievable and recommended.

\section{Archaeological and Historical Background}

At the time of sustained European contact in the early seventeenth century, Northern Iroquoian 
Table 1. All Radiocarbon Samples and Conventional Radiocarbon Ages (CRA) Used in This Study.

\begin{tabular}{|c|c|c|c|c|c|c|c|c|}
\hline $\begin{array}{l}\text { Dating Iroquoia } \\
\text { Project ID }\end{array}$ & Lab ID & Site & Context & Sample & $\delta^{13} \mathrm{C}$ & $\begin{array}{c}\text { CRA }{ }^{14} \text { C Years } \\
\text { Age BP }\end{array}$ & SD & $\begin{array}{c}68.2 \% \text { age } \\
\text { range Cal AD }\end{array}$ \\
\hline $\mathrm{n} / \mathrm{a}$ & $\mathrm{I}-6846$ & Sopher & Burned bark from ossuary lining & Burned bark & $\mathrm{n} / \mathrm{a}$ & 445 & 85 & $1405-1625$ \\
\hline Sopher_1 & VERA-6282 & Sopher & Archived site excavation collection & Zea mays & -8.6 & 364 & 27 & $1460-1620$ \\
\hline Sopher_1 & VERA-6282_2 & Sopher & Archived site excavation collection & Zea mays & -11.8 & 292 & 27 & $1523-1649$ \\
\hline Sopher_3 & UGAMS-40154 & Sopher & Archived site excavation collection & Zea mays & -9.10 & 287 & 23 & $1525-1650$ \\
\hline Sopher_4 & UGAMS-40155 & Sopher & Archived site excavation collection & Zea mays & -9.28 & 323 & 23 & $1518-1636$ \\
\hline $\mathrm{n} / \mathrm{a}$ & S-1535 & Benson & Charcoal from the site excavation, House 10 & charcoal & -25.0 & 430 & 80 & $1414-1625$ \\
\hline $\mathrm{n} / \mathrm{a}$ & S-1539 & Benson & Charcoal from the site collection, House 14 & charcoal & -25.0 & 620 & 70 & $1295-1397$ \\
\hline Benson_4 & UGAMS-33019 & Benson & Late phase, House 14 extension, Feature 2 & Zea mays & -9.27 & 289 & 21 & $1526-1648$ \\
\hline Benson_4 & UGAMS-33019r & Benson & Late phase, House 14 extension, Feature 2 & Zea mays & -9.27 & 304 & 21 & $1523-1644$ \\
\hline Benson_7 & GrM-14543 & Benson & Late phase, Midden 63, overlays House 6 floor & Zea mays & -10.51 & 342 & 20 & $1491-1631$ \\
\hline Benson_8a & UGAMS-33018 & Benson & Late phase, Midden 63, overlays House 6 floor & Zea mays & -9.28 & 302 & 21 & $1523-1644$ \\
\hline Benson_8b & GrM-14544 & Benson & Late phase, Midden 63, overlays House 6 floor & Zea mays & -7.97 & 305 & 20 & $1523-1643$ \\
\hline Benson_9a & UGAMS-33016 & Benson & Early phase, H6, intact living floor & Zea mays & -9.64 & 304 & 21 & $1523-1644$ \\
\hline Benson_9b & GrM-17562 & Benson & Early phase, H6, intact living floor & Zea mays & -10.26 & 352 & 20 & $1481-1625$ \\
\hline Benson_10 & GrM-14541 & Benson & Early phase, House 10 east extension, Feature 1 & Zea mays & -8.87 & 323 & 20 & $1518-1635$ \\
\hline Benson_11 & UGAMS-33017 & Benson & Early phase, House 10 west extension, Feature 2 & Zea mays & -8.98 & 320 & 21 & $1521-1636$ \\
\hline Ball_2 & UGAMS-34183 & Ball & Core, House 11, Feature 4 & Zea mays & -11.37 & 353 & 22 & $1478-1625$ \\
\hline Ball_2 & UGAMS-34183n & Ball & Core, House 11, Feature 4 & Zea mays & -10.62 & 333 & 19 & $1499-1633$ \\
\hline Ball_3 & UGAMS-34184 & Ball & Core, House 17, Feature 76 & Zea mays & -9.28 & 344 & 22 & $1490-1630$ \\
\hline Ball_3 & UGAMS-34184n & Ball & Core, House 17, Feature 76 & Zea mays & -8.74 & 353 & 19 & $1477-1625$ \\
\hline Ball_6 & UGAMS-34179 & Ball & Expansion, House 25, Feature 34 & Zea mays & -9.73 & 358 & 21 & $1470-1620$ \\
\hline Ball_6 & UGAMS-34179n & Ball & Expansion, House 25, Feature 34 & Zea mays & -9.28 & 351 & 21 & $1483-1625$ \\
\hline Ball_7 & UGAMS-34180 & Ball & Expansion, House 21, Feature 35 & Zea mays & -10.39 & 307 & 22 & $1522-1643$ \\
\hline Ball_7 & UGAMS-34180n & Ball & Expansion, House 21, Feature 35 & Zea mays & -9.34 & 298 & 19 & $1524-1645$ \\
\hline Ball_7 & UGAMS-34180r & Ball & Expansion, House 21, Feature 35 & Zea mays & -10.40 & 325 & 19 & $1516-1635$ \\
\hline $\mathrm{n} / \mathrm{a}$ & VERA-6309_1 & Warminster & House 4, Feature $16 \mathrm{~B}$ & Phaseolus sp. & -22.7 & 314 & 28 & $1521-1641$ \\
\hline $\mathrm{n} / \mathrm{a}$ & VERA-6309_2 & Warminster & House 4 , Feature 16B & Phaseolus sp. & -24.7 & 311 & 28 & $1521-1642$ \\
\hline $\mathrm{n} / \mathrm{a}$ & VERA-6309_3 & Warminster & House 4 , Feature 16B & Phaseolus sp. & -26.80 & 374 & 40 & $1451-1622$ \\
\hline $\mathrm{n} / \mathrm{a}$ & UGAMS-25450 & Warminster & House 4, Feature 16B & Phaseolus sp. & -24.60 & 363 & 22 & $1469-1619$ \\
\hline $\mathrm{n} / \mathrm{a}$ & VERA-6310 & Warminster & House 4 , Feature 12 & Prunus americana & -27.60 & 334 & 28 & $1494-1633$ \\
\hline $\mathrm{n} / \mathrm{a}$ & VERA-6310_2 & Warminster & House 4, Feature 12 & Prunus americana & -27.00 & 340 & 31 & $1490-1632$ \\
\hline $\mathrm{n} / \mathrm{a}$ & UGAMS-25451 & Warminster & House 4 , Feature 12 & Prunus americana & -27.19 & 427 & 22 & $1439-1457$ \\
\hline $\mathrm{n} / \mathrm{a}$ & UGAMS-25451u & Warminster & House 4, Feature 12 & Prunus americana & -27.61 & 365 & 21 & $1466-1618$ \\
\hline $\mathrm{n} / \mathrm{a}$ & UGAMS-25451-r2 & Warminster & House 4 , Feature 12 & Prunus americana & -27.27 & 355 & 22 & $1473-1625$ \\
\hline
\end{tabular}


Table 1. Continued.

\begin{tabular}{|c|c|c|c|c|c|c|c|c|}
\hline $\begin{array}{l}\text { Dating Iroquoia } \\
\text { Project ID }\end{array}$ & Lab ID & Site & Context & Sample & $\delta^{13} \mathrm{C}$ & $\begin{array}{c}\text { CRA }{ }^{14} \mathrm{C} \text { Years } \\
\text { Age BP }\end{array}$ & SD & $\begin{array}{l}68.2 \% \text { age } \\
\text { range } \mathrm{Cal} A D\end{array}$ \\
\hline $\mathrm{n} / \mathrm{a}$ & UGAMS-25451-r2r & Warminster & House 4, Feature 12 & Prunus americana & -27.81 & 368 & 21 & $1463-1617$ \\
\hline $\mathrm{n} / \mathrm{a}$ & UGAMS-25451-r & Warminster & House 4, Feature 12 & Prunus americana & -27.14 & 396 & 21 & $1448-1485$ \\
\hline $\mathrm{n} / \mathrm{a}$ & UGAMS-25451-rr & Warminster & House 4 , Feature 12 & Prunus americana & -27.96 & 346 & 21 & $1488-1630$ \\
\hline $\mathrm{n} / \mathrm{a}$ & Wk-42865 & Warminster & House 4, Feature 13 & $\begin{array}{l}\text { Larix laricina, } \\
\text { Rings 9-17 }\end{array}$ & $\mathrm{n} / \mathrm{a}$ & 355 & 17 & $1475-1620$ \\
\hline $\mathrm{n} / \mathrm{a}$ & Wk-42866 & Warminster & House 4, Feature 13 & $\begin{array}{l}\text { Larix laricina, } \\
\quad \text { Rings 19-27 }\end{array}$ & $\mathrm{n} / \mathrm{a}$ & 325 & 15 & $1519-1634$ \\
\hline $\mathrm{n} / \mathrm{a}$ & Wk-42867 & Warminster & House 4, Feature 13 & $\begin{array}{l}\text { Larix laricina, } \\
\quad \text { Rings } 29-37\end{array}$ & $\mathrm{n} / \mathrm{a}$ & 349 & 13 & $1487-1621$ \\
\hline $\mathrm{n} / \mathrm{a}$ & Wk-42868 & Warminster & House 4, Feature 13 & $\begin{array}{l}\text { Larix laricina, } \\
\quad \text { Rings } 39-47\end{array}$ & $\mathrm{n} / \mathrm{a}$ & 321 & 15 & $1521-1635$ \\
\hline $\mathrm{n} / \mathrm{a}$ & Wk-42869 & Warminster & House 4, Feature 13 & $\begin{array}{l}\text { Larix laricina, } \\
\quad \text { Rings } 49-57\end{array}$ & $\mathrm{n} / \mathrm{a}$ & 317 & 14 & $1522-1638$ \\
\hline Warminster_4 & UGAMS-34181 & Warminster & House 9 , Feature 30c & Zea mays & -9.46 & 365 & 21 & $1466-1618$ \\
\hline Warminster_8 & UGAMS-34182 & Warminster & House 5, Feature 1 & Zea mays & -10.85 & 326 & 21 & $1515-1635$ \\
\hline
\end{tabular}

Notes: Individual 68.2\% most likely calibrated ages from OxCal 4.3.2 (Bronk Ramsey 2009a) and IntCal13 (Reimer et al. 2013) with a curve resolution set at five years given as a guide; see especially the wide and ambiguous (100+ years) dating of most of these samples when considered in isolation. For the individual nonmodeled calibrated age ranges at $68.2 \%, 95.4 \%$, and $99.7 \%$ probability, see Supplemental Table 1. Samples with the same Dating Iroquoia Project ID are the same sample, e.g., a single organic specimen that has been divided to obtain multiple measurements.

UGAMS Lab ID designations are as follows: $\mathrm{n}$ or no alphabetic label $=$ New pretreatment as per Cherkinsky et al. $(2010) . \mathrm{u}=$ No pretreatment. Sample combusted at $900^{\circ} \mathrm{C}$ in an evacuated and sealed quartz tube in the presence of $\mathrm{CuO}$ to produce $\mathrm{CO}_{2}$, which was then dated by the AMS. $\mathrm{r}=\mathrm{A}$ remnant of the original pretreated sample was combusted without additional pretreatment at $900^{\circ} \mathrm{C}$ in an evacuated and sealed quartz tube in the presence of $\mathrm{CuO}$ to produce $\mathrm{CO}_{2}$, which was then dated by the AMS $(\mathrm{Cherkinsky} \mathrm{et} \mathrm{al.} \mathrm{2010).} \mathrm{r} 2=\mathrm{Complete}$ reanalysis starting with untreated sample following standard UGAMS AAA pretreatment; then sample combusted at $900^{\circ} \mathrm{C}$ in an evacuated and sealed quartz tube in the presence of CuO to produce $\mathrm{CO}_{2}$, which was then dated by the AMS (Cherkinsky et al. 2010). Note: this reanalysis date is significantly different (more than 2 SD) from the original date (a chi-squared test shows the two dates are not compatible at the $95 \%$ level with being the same radiocarbon age: $\chi^{2}$ df1, T $=6.4>3.8$ [Ward and Wilson 1978]). r2r $=$ Remnants of UGAMS-25451-r2 were subjected to a second AAA pretreatment and then usual combustion at $900^{\circ} \mathrm{C}$ in an evacuated and sealed quartz tube in the presence of $\mathrm{CuO}$ to produce $\mathrm{CO}_{2}$, which was then dated by the $\mathrm{AMS}(\mathrm{Cherkinsky} \mathrm{et} \mathrm{al.} \mathrm{2010).} \mathrm{rr}=$ A remnant of the original pretreated sample (as used for UGAMS-25451) was subjected to a second AAA pretreatment and then combusted at $900^{\circ} \mathrm{C}$ in an evacuated and sealed quartz tube in the presence of $\mathrm{CuO}$ to produce $\mathrm{CO}_{2}$, which was then dated by the AMS (Cherkinsky et al. 2010).

The listed UGAMS and GrM $\delta^{13} \mathrm{C}$ values are from independent IRMS analysis. The VERA values are those from the AMS. The Wk AMS ${ }^{14} \mathrm{C}$ dates, with target preparation at Waikato and the samples then run at the W. M. Keck Carbon Cycle Accelerator Mass Spectrometry Laboratory, are corrected for isotopic fractionation but do not have publicly released $\delta^{13} \mathrm{C}$ information. This reflects the policy of the Keck Laboratory not to release AMS-produced $\delta^{13} \mathrm{C}$ values, which necessarily include fractionation and can thus be misleading.

The Isotopes Inc. conventional radiocarbon result from the Sopher site, I-6846, is not corrected for isotopic fractionation. However, the dated material, stated as burned bark, should have a similar value to wood and thus be little affected by the absence of correction for isotopic fractionation (versus the assumed typical wood value used). And so we employ it as published. For I-6846, see Buckley (1976:184). There is no mention of isotopic correction for the University of Saskatchewan dates from the Benson site, S-1535, S-1539 (Rutherford et al. 1981:126) either in the Rutherford and colleagues (1981) report or in the earlier laboratory statements cited there. Again, samples of charcoal should not be significantly affected by this absence, and so we use the date as published.

The "n/a" means these samples were collected and dated prior to the Dating Iroquoia project, either as found in previous literature (I-6846, S-1535, S-1539 from, respectively, Buckley 1976; Rutherford et al. 1981) or as published in Manning and colleagues (2018).

Benson_9b sample: GrM-17562. We note that there was a previous, now failed, date for this sample that was anomalously too old. The original date on this sample, GrM- $14545,443 \pm 20{ }^{14} \mathrm{C}$ years $\mathrm{BP}$, was clearly a too old outlier. The sample was re-pretreated from scratch, remeasured, and a much later date achieved that was compatible with the other Benson data: this is GrM-17562, which we use. In the absence of any other explanation, we have to assume that in the processing of the sample for the original GrM-14545 date, some old carbon was accidentally incorporated into the dated target. Hence GrM-14545 is regarded as "failed" and is not used. 
peoples comprised confederacies of allied Nations and clusters of associated settlements occupying regions adjacent to the Lower Great Lakes, St. Lawrence Valley, and the Finger Lakes Regions of Ontario, Québec, and New York State. This article focuses on the ancestors of the contemporary Huron-Wendat Nation. Between the thirteenth and seventeenth centuries ancestral Huron-Wendat peoples transitioned from groups occupying small agricultural village communities to a suite of allied Nations sharing a territory located immediately southeast of Georgian Bay, a large bay of Lake Huron (Birch 2015; Trigger 1976; Williamson 2014: Figure 1).

The Benson, Sopher, Ball, and Warminster sites were villages of the Wendat Arendarhonon Nation (Trigger 1976:156) or "people at the rock" (Steckley 2007:37; anglicized as the Rock Nation). A well-known sequence of large pre- and protohistoric villages in the Upper Trent Valley has been interpreted as representing that ancestral population (e.g., Ramsden 1990, 2016a).

Based on archaeological and historical knowledge, Benson is understood to be one of the last sites in the upper Trent Valley before a population move to the area west of Lake Simcoe, where the Sopher, Ball, and Warminster sites are located (Trigger 1976:156). This 1.5 ha village was excavated in the 1970s (Fogt and Ramsden 1996; Ramsden 1978, 1988, 2009; see Figure 2a). Its occupation has been estimated as starting around 1550 (Ramsden 2016a) or 1570 (Ramsden 2016b) and ending by about 1590 (Ramsden 2016a; Williamson 2014) or 1600 (Ramsden 2016b) based on ceramic seriation and the presence of some European metals. Two primary lines of evidence suggest that the Benson site is earlier than the other Arendarhonon sites. The first is ethnohistoric. Writing about the Arendarhonon in 1636, the Jesuit Lalemant asserts that they came to the country some 50 years earlier (Thwaites 1896-1901:16:227), interpreted as about 1590 (Williamson 2014:34). Members of the Arendahronon told Champlain that they formerly lived in the Trent valley and had abandoned the area because of fear of their Haudenosaunee enemies (Biggar 1922-1936:3:59). Although the Arendarhonon had a clear interest in the Trent Valley (Trigger 1976:156), it was reportedly abandoned by the time Champlain passed through with the assembled Wendat war party in 1615. The second line of evidence comprises the European trade goods from Benson, which suggest that it dates to the period of very early European contact and so before the last decades of the sixteenth century. Ramsden (2009) notes that fragments of European metal-but no glass beads-were found only in House 10 at the site, which he interprets as the leading household in a community faction with strong ties to the St. Lawrence Valley and very early European trade connections. Although we seek to avoid circular reasoning and periodization based on trade good frequencies in this article, the ethnohistoric evidence together with the limited presence of trade goods suggests an occupation prior to Ball that has glass beads of both Glass Bead Periods (GBP) 1 and 2 (Fitzgerald 1986:4).

The Sopher and Ball sites are thought to have been among the pioneering Arendarhonon settlements in historic Wendake. Sopher is best known for excavations of its ossuary, including the recovery of an iron celt (Noble 1971). Limited excavations in the 1.5 ha village revealed two longhouses and a number of middens, although no palisade (Noble 1968; Sykes 1980). On the basis of its small trade good assemblage, Sopher is thought to date to the mid to late sixteenth century (Noble 1968, 1971); thus, it is one of the likely earliest Arendarhonon sites to relocate from the Trent Valley and to have contributed population to the later Arendarhonon sequence.

Ball is a 3.5 ha village that was excavated in its entirety by Dean Knight (1987) in the 1970s and 1980s (see also Martelle 2002; Michelaki et al. 2013; see Figure 2b). Its size suggests that it was the principal village of the Arendarhonon. Based on the similar sizes and proximity of Ball and Warminister, together with interpretations of the ethnohistoric record, it has been assumed that Ball dates to the late sixteenth or early seventeenth centuries and that the Warminster site followed Ball as the primary village in the historic Wendake Arendarhonon sequence (Heidenreich 1971, 2014; Williamson 2014).

The Warminster site was first identified by Andrew Hunter (1902) as a large contact-period 
village with two associated ossuaries, one of which was heavily looted in the late nineteenth century (Heidenreich 2014:24; Sykes 1983). The site was subject to intermittent excavations between the 1940s and 1970s (Mcllwraith 1946; Sykes 1983). Warminster is essentially a double village, consisting of two palisaded sections located approximately $165 \mathrm{~m}$ apart (Figure 2c-e). The north village is 3.4 ha in size, and the south village is $2.6 \mathrm{ha}$. Seven complete longhouses and portions of 13 more were reported from the northern village (Sykes 1983:81, 85). Similarities in the material culture assemblages recovered from each section of the site suggest that they were occupied contemporaneously (Williamson 2014:34). Possible ethnohistoric associations, trade good frequencies, and artifact types have at different times been used to suggest that either Ball preceded Warminster, or vice versa (e.g., Fitzgerald 1986, 1990; Fitzgerald et al. 1995; McIlwraith 1947). Such debate and ambiguity provide good reason to seek independent radiocarbon confirmation of the dating of these two sites.

\section{Warminster as Cahiagué: History of the Debate}

\section{Historical and Linguistic Evidence}

The primary ethnohistoric documents cited in the Cahiagué debate were written by Samuel de Champlain (Biggar 1922-1936) and Gabriel Sagard (Wrong 1939). Champlain first visited the Atlantic coast of eastern North America in 1603 before establishing a settlement at what is now Québec City in 1608. In his explorations, he interacted with many Indigenous peoples seeking to develop alliances and trade relations. He was well aware of the enmities that existed between various nations, some of which he perceived as impediments to the diplomatic and economic interests he sought to extend on behalf of France. For these reasons, in 1615, he agreed to join a party of Wendat allies in a raid against the Onondaga, a Haudenosaunee nation in what is now New York State. Accompanied by a contingent of men, he traveled through the country of the Attignawantan ("of bear country" [Steckley 2007:36], the largest and northernmost of the Wendat Nations) to the Arendarhonon, from whose territory the raid would depart. In August 1615, according to his account, he "visited five of the principal villages, enclosed by wooden palisades, as far as Cahiagué, the principal village of the country, which contains two hundred fairly large lodges and where all the warriors were to assemble" (Biggar 19221936). It is generally agreed that Champlain's estimate of the number of houses was at best a rough guess (e.g., Heidenreich 2014:22). Since Ball and Warminster are believed to be successive iterations of the same community, both may have been the "principal village of the country" (in turn). Along the journey, he notes that they traveled along a "strait" that connected to a larger lake, which is generally interpreted as being Lakes Couchiching and Simcoe (see Figure 1). About September 8, Champlain set off to the eastern Haudenosaunee territory with approximately 500 Wendat and Algonquin warriors. Champlain was wounded during the campaign and returned to Cahiagué on December 23. He remained among the Wendat, both at Cahiagué and traveling within the region, until May 1616.

Sagard was a Recollect lay brother who lived among the Wendat from the summer of 1623 to the autumn of 1624. His writings include detailed descriptions of Wendat life and customs (Wrong 1939), as well as a dictionary of the Wendat language (Steckley 2009). Although Sagard is recognized as the first "ethnographer" of the Wendat, portions of his writings are extensively reproduced from Champlain's own accounts. When Sagard arrived at Cahiagué in 1624 , he reported that "the chief town formerly contained two hundred large lodges, each filled with many households; but of late, on account of the lack of wood and because the land began to be exhausted, it has been reduced in size, divided in two, and rebuilt in another more convenient locality" (Wrong 1939:92). It is unclear whether this passage should be interpreted as the village being (1) divided in two, with each part rebuilt adjacent to each other, as is the arrangement at Warminster; (2) divided with its population relocating to two new settlements located at some distance from one another; or (3) divided in two with some portion of the 

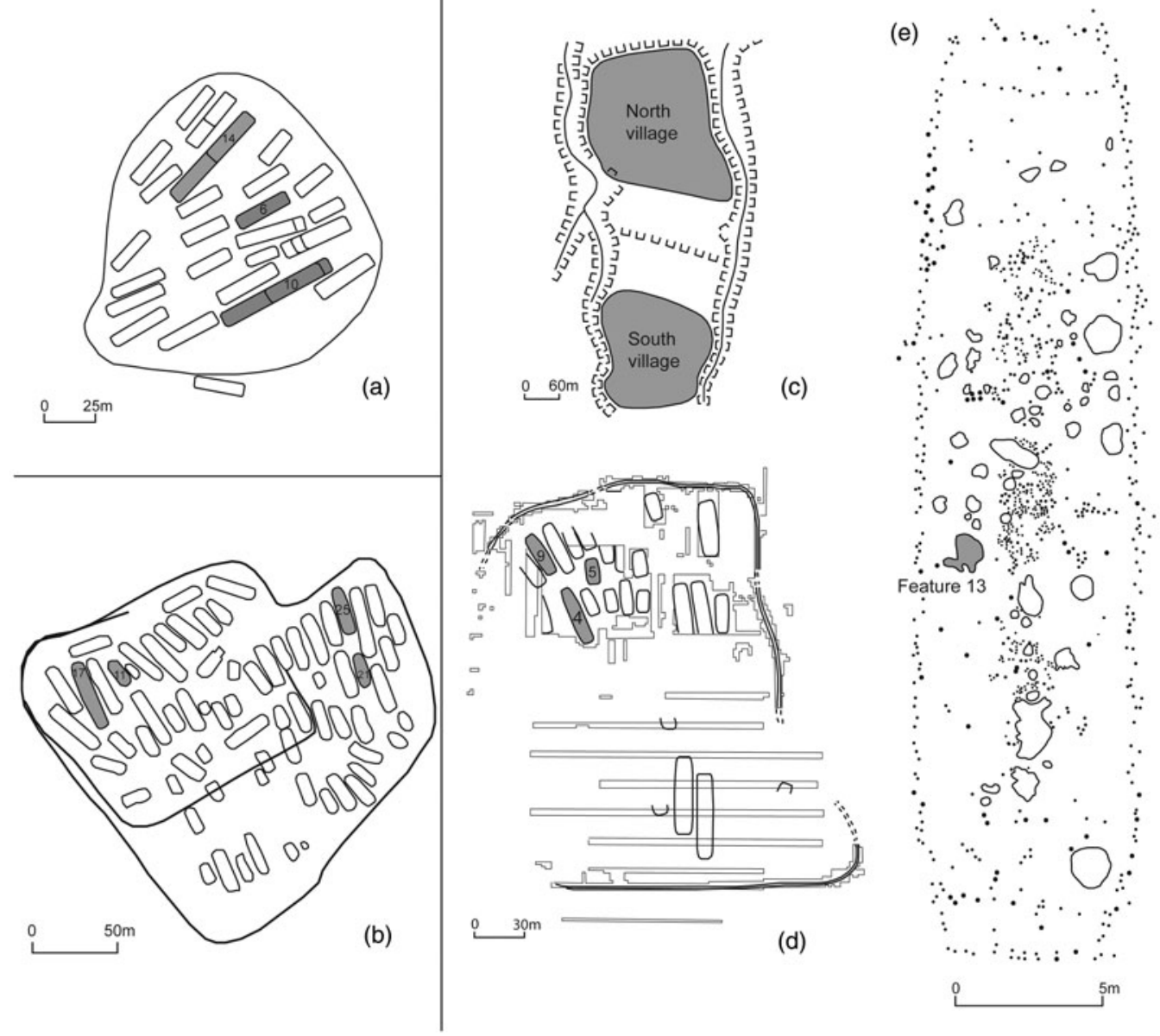

Figure 2. (a) Benson site plan, modified after Ramsden (2009); (b) Ball site plan, including sites identified in text, modified after Michelaki and others (2013); (c) Overall Warminster site plan, north and south villages indicated; (d) North village plan, including locations of Houses 4, 5, and 9 from which samples were obtained; (e) Plan of House 4 indicating the location of Feature 13. Images c, d, and e are all modified after Sykes (1983).

community remaining behind in the preexisting settlement.

Heidenreich $(1971,2014)$ has been one of the staunchest proponents of the identification of Warminster as Cahiagué. He has defended this attribution based on Champlain's accounts of the direction and distance traveled between bodies of water and the villages, the large size of the village, and his analysis of the word Cahiague as meaning "place divided in two" (Heidenreich 1971:303) or "it is cut in two" (Steckley 2007:142). However, as Trigger (1976:304) has noted, "It is strange that Champlain would not have mentioned such an unusual feature as the village being divided into two separately palisaded units." This seems especially so given his close eye to military matters in the remainder of his account. As such, interpretive difficulties in both Champlain's and Sagard's accounts call the identification of Warminster as Cahiagué into question.

\section{Trade Goods}

Fitzgerald (1986) notes that in 1615 Champlain was attempting to establish more secure trade connections with the Huron, the Arendarhonon specifically. The Arendarhonon were the first Wendat nation to meet and conclude an alliance 
with the French (Thwaites 1896-1901:20:19; Trigger 1976:246). As per Wendat custom, the lineage whose members first discovered a trade route claimed rights to it (Trigger 1976). Assemblages of trade goods, including European metals and glass beads, have been identified at both the Ball and Warminster sites (Fitzgerald 1986: Tables 1-2, 1990:Table 10; Fitzgerald et al. 1993; Sykes 1983). The Ball site contains glass beads associated with GBP1 and GBP2, whereas the Warminster site contains beads that date overwhelmingly to GBP2 (Fitzgerald at al. 1995: Table 2). In Ontario, there is general agreement that GBP1 dates to 1580-1600 (Garrad 2014; Kenyon and Fitzgerald 1986; Kenyon and Kenyon 1983); however, the most recent and complete review of trade bead assemblages from the region advises exercising caution about the beginning and ends of such relative, assemblagebased chronologies, drawing attention to distinct regional exchange and supply networks and associated variations in assemblage content between regions (Loewen 2016).

The assignment of dates for the beginning and end of GBP2 has in fact hinged on the Cahiagué debate. Kenyon and Kenyon (1983) dated the Period 2-3 transition to 1616-1624, believing Warminster to be Cahiagué. They based the start of the transition on the date of Champlain's stay and the end on their interpretation of Sagard's claim that the village had been abandoned by 1624 (Wrong 1939:92). Based on his assessment of the trade bead assemblages and the assertion that Ball is most likely the village visited by Champlain in 1615-1616, Fitzgerald dated the GBP2-GBP3 transition to much later: 1628-1632 (1986:3-7; Kenyon and Fitzgerald 1986:15). A subsequent reassessment of the Ball site trade bead assemblage by Fitzgerald and colleagues (1995) suggested that Ball dates to about 1585-1605 and Warminster to 16051623. This reassessment was based on historical and archival evidence of European trade shipments and merchant activity on the east coast and the St. Lawrence corridor.

In both of these assessments, potential problems derive from making absolute date determinations based on the relative presence of trade goods on Indigenous sites, interpretations of Sagard's imperfect descriptions of the nature of the village's relocation and/or division in 1624, and the assumption that both villages are perfectly sequential. For example, Margaret Thompson (in McIlwraith 1946:400) notes that European goods were only found in the upper layers of midden deposits at Warminster, suggesting that the settlement was initially occupied prior to the widespread circulation of European material. A similar argument has been used to justify the Sopher village's mid to late sixteenth-century date (Noble 1968, 1971; Williamson 2014).

Although there have been advances in research on the temporal implications of the geochemical composition of glass beads (e.g., Bonneau et al. 2013; Hancock 2012; Hancock et al. 2000; Walder 2013), these studies often relate to assemblages postdating 1630 (after the period in question here), and they rely on archaeologically based chronologies and broad intervals in which certain bead types were being produced in European manufacturing facilities. Rather than serving to date the time at which these items were used and deposited into the archaeological record, they ultimately date the time at which they were manufactured. This makes these innovative techniques useful complements to existing relative chronologies, but with less precision than the AMS radiocarbon-based methods employed here.

Recent research on the chemical composition and distribution of trade copper has indicated that trade and exchange patterns among the Indigenous peoples in Québec and Ontario were more complex than was previously thought and that the population inhabiting the Ball site may have had preferential access to European material in the early contact era (Pavlish et al. 2018). This research also recognizes that different communities had heterogeneous trading connections (see also Jones et al. 2018), further supporting the need for chronology building that is independent of trade goods and the inherent assumptions involved in the associated scholarly tradition (see also Manning et al. 2018). Trade good chronologies, including the Ontario glass bead chronology, are ultimately relative dating techniques, which are underlain by acculturative assumptions about the way goods of European origin filtered through Indigenous trade networks. For these static chronologies to hold 
true, European goods would have to have spread through Indigenous networks in a time-andspace transgressive manner, uninhibited by cultural preferences, differing Indigenous attitudes, and differential access to trade routes and trading partners. Clearly, acquiring many more secure and absolute radiocarbon dates from contexts associated with trade beads and other chronologically distinct assemblages will help confirm Ball and Warminster's dates of occupation and refine the larger contact-era chronology for the region, including inferences about spatial and temporal trade good distributions. Such independent, refined chronologies are a necessary precursor to further systematic assessment of absolute dates for historical sites and associated material culture through radiocarbon dating, both in Iroquoia and North America more broadly (see also Thompson et al. 2019).

\section{Samples and Methods}

\section{Samples and Radiocarbon Dates}

We recognize that secure stratigraphic provenance for radiocarbon samples from such shallow and usually one-phase Iroquoian sites is sometimes problematic. Our aim was to avoid any material merely from the locus (thus potentially from a contaminated surface find) and to date material stated or reasonably assumed to come from the archaeological excavation of the site (nonsurface finds). Where possible (as in the research reported here), we avoided faunal remains (like deer elements) that could have derived from natural or nonsite occupation hunting episodes. Although it is difficult to assert our findings with total confidence, the fact that we achieve sets of coherent age estimates with only occasional outliers (see the later discussion) suggests we are likely dating the Iroquoian contexts of interest for each site.

The current study (see also Manning et al. 2018) is the first to radiocarbon date materials from Ball or Warminster. Two published dates on charcoal samples exist for Benson (Rutherford et al. 1981:126) and one for Sopher (Buckley 1976:184). Samples of carbonized maize (Zea mays) were acquired from cultural features in three houses (Houses 6, 10, and 14) and a midden (Midden 63) at the Benson site (Figure 2a): these contexts comprise an original or earlier site phase and then a subsequent later site phase including a house extension (House 14) and the stratigraphically overlaying Midden 63 above the House 6 floor. Samples of carbonized maize were acquired from collections associated with excavations at the Sopher site (Noble 1968), although they lack specific provenience below the site level. Samples of carbonized maize from the Ball site were acquired from curated feature contexts excavated within Houses 11 and 17 from the older, core site and from Houses 21 and 25 in the later expanded site area (Figure 2b). No associated field notes were available to provide additional contextual data for the samples.

For the Warminster site, both short-lived and dendrochronological samples were acquired, including the remains of a Larix laricina post associated with Feature 13 (Cat \#27442) from House 4 at the site (Figure 2d-e). Feature 13 was described in the field notes as a "small, shallow stain" (Kathryn David, personal communication 2017). The location of this feature and its relatively narrow overall diameter suggest that it may have comprised a support for a bench or bunk line. Similar supports are visible in the House 4 plan to the east and south of Feature 13 (Figure 2e). William Fox (personal communication 2015), who participated in excavations at the site in the 1960s, recalled that palisade posts also were observed intact in the field, suggesting that similarly sized structural remains were likely present in the village itself. A dendro-wiggle-match date for the last preserved ring on the post, previously described by Manning and colleagues (2018), comprised 57 tree rings with inner tree rings and pith absent. There was no bark and the sample was only partially preserved, so the number of tree rings missing from the extant outer ring of the sample to the original bark is not known. Many of the tree rings from the post are narrow, so even a relatively small amount of missing outer wood, and thus rings, could easily represent a few decades of time. The modeled age for the last extant tree ring is thus likely an early TPQ for the occupation period of the site (Supplemental Figure 1). A sample of bean (Phaseolus sp.) from Feature 
$16 \mathrm{~B}$ and a sample of wild plum (Prunus americana) from Feature 12 also were obtained, both from House 4. All three features are from the center area inside the longhouse (Sykes 1983:Figure 15). Additional samples of maize from House 9, Feature 30c and House 5, Feature 1 (Figure 2d) were acquired to provide additional context from the surrounding village. All Warminster samples are from the northern village.

We obtained radiocarbon dates on these samples (Table 1; Supplementary Table 1). The calibrated calendar probability distributions from each date are shown against the IntCal13 radiocarbon calibration curve (Reimer et al. 2013, the current calibration curve at the time of writing) in Figure 3. The nonmodeled calibrated ranges for these dates are shown in Figure 4. We observed, as expected, the ambiguous situation for radiocarbon dates in the period around AD 1500-1600 where, because of the reversal and plateau in the calibration curve, calibrated calendar dating probability can seem to offer multiple date possibilities over a wide (and thus unhelpful) range. For this reason, we applied Bayesian chronological modeling approaches to overcome this inherent ambiguity.

\section{Bayesian Chronological Modeling}

We analyze the dataset using the IntCal13 radiocarbon calibration curve with curve resolution set at one year and employing Bayesian chronological modeling via OxCal 4.3 to incorporate prior information (Bronk Ramsey 2009a, 2009 b). Bayesian modeling is a powerful statistical method that permits the incorporation of both prior information (archaeological and historical information) and new data (radiocarbon dates) to constrain possible solutions and so refine understandings of age estimates and associated questions (Bayliss 2009; Bronk Ramsey 2009a). It should be noted that, once calibrated, radiocarbon dates, and subsequent modeling thereof, have probability density functions that are not normally distributed, and therefore, results are presented as highest posterior density (hpd) ranges and not as a value within standard deviations.

Contrary to a situation where there is a known order of strata/phases from stratigraphy (the classic prior knowledge for Bayesian chronological modeling; Buck et al. 1991), for these Iroquoian sites, we can be independently sure of either the direct sequence relationships or the order of the sites only infrequently. If we are to avoid circular logic where we merely seek to confirm what is already assumed, we must instead consider the radiocarbon evidence first independently. Thus we begin with the radiocarbon data from our four sites and query whether these data suggest an order among the sites independent of prior assumptions. If we consider the four sites as independent sequences within an OxCal Phase (so the sites may overlap, be separate, or be contiguous in calendar time as the data indicate and not as we assume), we may use the Order function in OxCal to determine the probabilities of the order in calendar time of the dated and modeled elements. The order analysis considers the probability that term $1\left(\mathrm{t}_{1}\right)$ is older than term 2 $\left(t_{2}\right)$. For this analysis, we exclude the three ${ }^{14} \mathrm{C}$ dates run on charcoal or bark samples-it is unclear whether I-6846 is just outermost bark, and thus it is best considered as wood-charcoal: its ${ }^{14} \mathrm{C}$ age is substantially older than the dates on short-lived samples from Sopher-both because they only offer clearly old TPQs versus date estimates for the site phase and all have large measurement errors.

There is one additional necessary assumption. As noted earlier, the sixteenth-century reversal/ plateau in the ${ }^{14} \mathrm{C}$ calibration curve offers multiple possible ranges for dates in the period we are addressing and spreads possible dating probability out over the calendar time scale (Figures 3 and 4; Supplemental Table 1). However, we have strong indications from ethnohistoric sources and archaeological considerations that typical Iroquoian settlements were not long-lived. Champlain's account of contact period village relocation suggests that "they sometimes change their village site every ten, twenty, or thirty years" (Biggar 1929:3:124). Although the very short earlier seventeenth-century village occupations that were ethnographically reported may not have been typical of earlier periods, no evidence points to occupation periods longer than several decades; for example, around 30 years (Fitzgerald et al. 1995:127-131). Warrick's (1988:47) analysis of wall post density in the longest-lived or "core" houses in a community 
suggests that the Ball and Warminster sites were occupied for "comparable" periods of time, some 13 and 17 years, respectively. Sykes (1980) estimated that Warminster would have been abandoned after 12 years because of depleting crop yields, as determined based on soil types in the site's agricultural catchment. Based on syntheses of archaeological and ethnohistoric information, contact period village duration has been estimated at, on average, 15-20 years (Biggar 1922-1936:3:124; Fitzgerald 1986:120; Thwaites 1896-1901:10:275, 15:153; Wrong 1939:92), and from the discussion of Warrick (1988) in general, we might infer a maximum span of such villages at about 40 years. Thus, even if we regard this "short" lifetime as itself an ingrained assumption in need of some critical examination, everything indicates relatively short-lived sites. Long site durations appear $\mathrm{cul}$ turally impossible, despite the ${ }^{14} \mathrm{C}$ calibration curve taphonomy encouraging this possible outcome.

Hence, after an initial model with all data that demonstrates the potential problem of much too overlong phases in the absence of any duration constraints (Model 1, Supplemental Figure 2), with improbable calculated site phase durations at $68.2 \%$ and $95.4 \%$ probability from an example typical run (with Amodel 96, Aoverall 99) of Benson 0-74 years (68.2\%), 0-171 years (95.4\%); Sopher 0-143 years $(68.2 \%), 0-514$ years $(95.4 \%)$; Ball $0-184$ years $(68.2 \%), 0$ 521 years $(95.4 \%)$; and Warminster $0-54$ years (68.2\%), 0-120 years (95.4\%) (Supplemental Figure 3; Supplemental Table 2), we constrain the period of time represented by each site phase (that is between the OxCal Boundaries for the start and end of the relevant $\mathrm{OxCal}$ Phase-we are assuming that the dates in each OxCal Phase are a set of estimates randomly sampled from a uniform distribution). On a conservative basis, we consider restricting possible total site phase durations to a uniform probability range of between $0-50$ years to 0-120 years-thus, longer than the maximum expected 0-40-year range from ethnohistoric and archaeological assessments to three times this maximum range-by constraining an OxCal Interval query for each site phase (Model 2).
We checked for and downweighted the influence of outliers among the samples in our models using variously two or three of the outlier models in OxCal (Bronk Ramsey 2009b). Outlier analysis of the dates in the wiggle-match employed the SSimple Outlier model. For the dates on charcoal and the Sopher "tree bark" date, which we assume may not only include the outermost bark, we applied the Charcoal Outlier model to allow approximately for the in-built age expected in these samples. Outlier analysis for the short-lived (annual) plant matter (individual dates or the R_Combine groupings) employed the General Outlier model. Where radiocarbon dates were run on the very same short-lived sample (and hence the ${ }^{14} \mathrm{C}$ ages measured should each be estimates of the same real ${ }^{14} \mathrm{C}$ age), we employed a weighted average age (Ward and Wilson 1978) using the R_Combine function, including an additional eight radiocarbon years to allow for annual-scale variation in this period (Stuiver and Braziunas 1998). We employed the SSimple Outlier model for the individual data within the R_Combine and the General Outlier model for the R_Combine itself (following the coding examples in Higham et al. 2014). Outlier analysis is reported with the first number as the posterior outlier probability (in percent) and second number as the prior outlier probability (e.g., O:3/5, $3=$ posterior outlier probability, $5=$ prior outlier probability). The date is considered a possible outlier when the posterior probability is greater than the prior level of $p=0.05$, or $5 \%$ (i.e., the posterior probability of being an outlier is above the acceptable level of $5 \%$ probability). In the initial Model 1 , considering each site independently to investigate likely site order, only one date was found to be a very clear outlier ( $>50 \%$ probability) over multiple runs: UGAMS-25451 (O:92/5 or 91/5), too old. Rerunning Model 1 minus UGAMS-25451, just one date remains as a larger outlier, being greater than 7\%: UGAMS-25451-r (O:22/5). This is again too old-although in this case and for UGAMS-25451, this old age may reflect the calibration curve taphonomy and the marked wiggle $\sim 1603-1607$ (Manning et al. 2018:Figure S5). We therefore exclude these two dates from the analysis in Model 2, which runs with no outliers above $7 \%$ probability and 


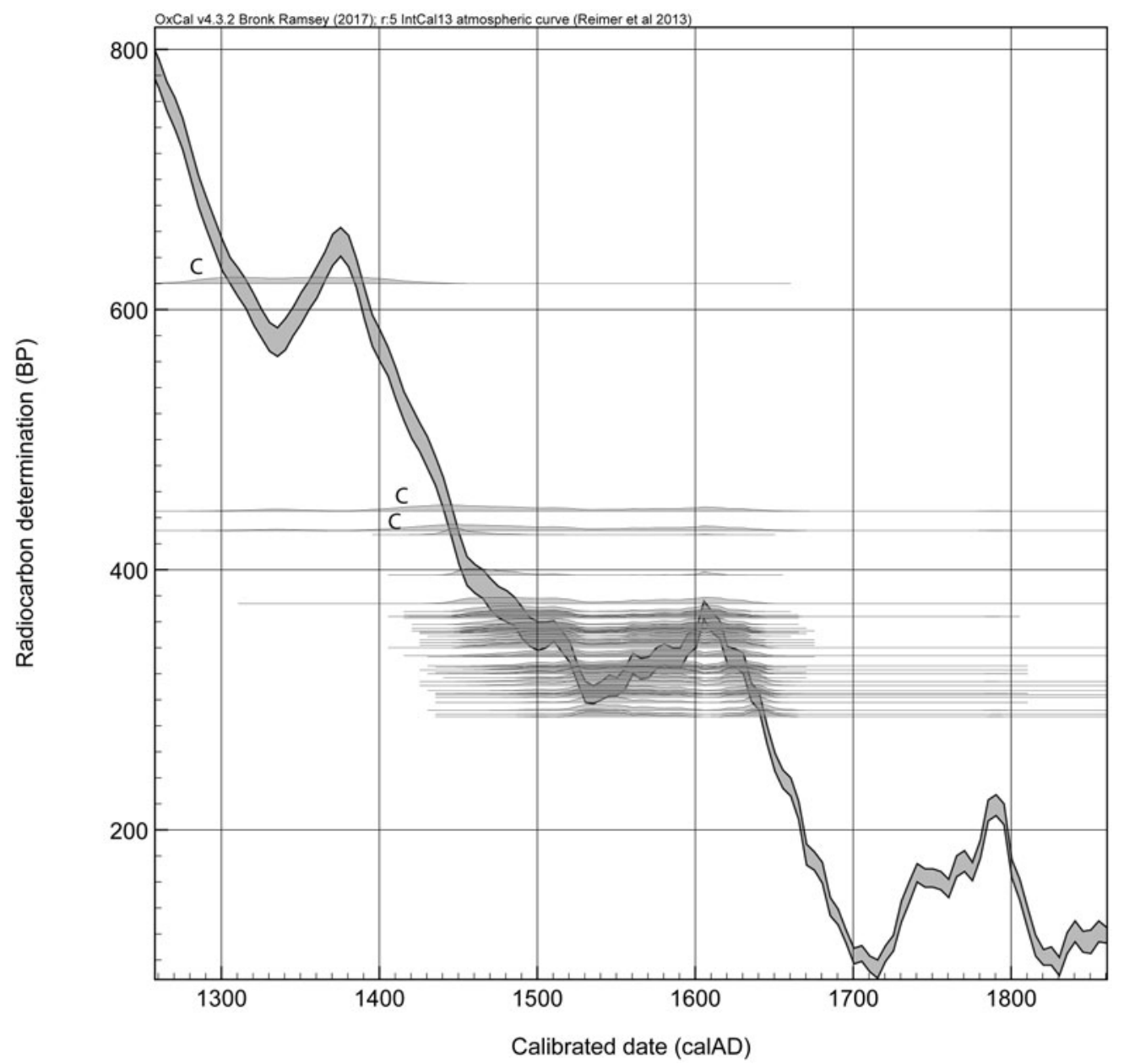

Figure 3. The calibrated calendar age probability distributions for the 45 radiocarbon dates in Table 1 shown against the IntCal13 radiocarbon calibration curve (Reimer et al. 2013). The ambiguity created by the "wiggle"/plateau between about 1500-1620 is evident. The calibrated probabilities from the three dates run some time before this project on charcoal samples are labeled "C."

good Amodel and Aoverall OxCal diagnostic values. Model 2 forms the basis of our order analysis. It is important to note that complex OxCal models yield very slightly different results in each run, and sometimes runs do not converge. Here we show typical results from multiple runs and report only runs that completed with acceptable Amodel and Aoverall values $(\geq 60)$ and with convergence $(\mathrm{C})$ values for each dated element $\geq 95$.

The analysis comprises two stages. In Stage 1 we consider whether a likely relative order could be determined among the four sites (Model 1; see Supplemental Figures 1-3, leading to Model 2). In Stage 2, we then analyze the site phases in terms of the relative order resolved in Stage 1 from Model 2 as a sequence in OxCal (Models 3-6). For Stage 1, the order probabilities determined from Model 2 are detailed for the start and end boundaries for each overall site phase and for a date estimate for each overall site phase across iterations of Model 2 with site phase OxCal Interval queries constrained to 0 $50,0-60,0-70,0-80,0-90,0-100$, and 0-120 years in Supplemental Table 3. The OxCal Date estimate determines a hypothetical event that describes the full temporal extent of the phase. If the start and end boundaries were known exactly, then this date would cover the length of the phase; however, because the start 


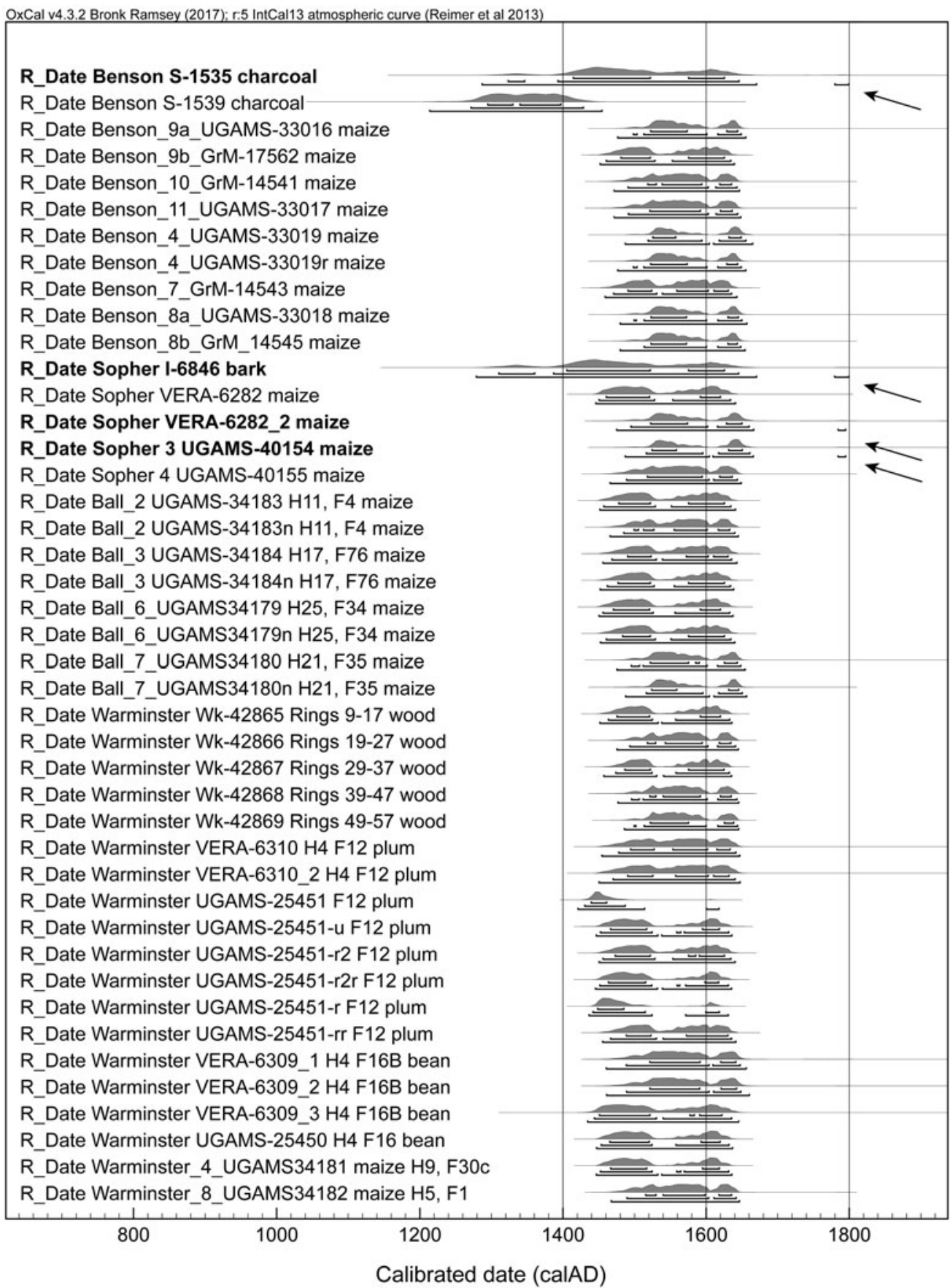

Figure 4. Individual nonmodeled calibrated calendar age ranges for the radiocarbon dates in Table 1 at $68.2 \%, 95.4 \%$, and $\mathbf{9 9 . 7 \%}$ probability from IntCal13 (Reimer et al. 2013) employing OxCal (Bronk Ramsey 2009a) with curve resolution set at five years. The arrows indicate the four dates (in bold) where at extreme margins they could include post-1661 calibrated calendar date ranges. For ranges, see Supplemental Table 2. 
Table 2. Model 2 Average Order Analysis Probabilities for Site Phase Interval Constraints.

\begin{tabular}{|c|c|c|c|c|c|c|c|c|c|c|c|c|}
\hline \multirow[t]{2}{*}{$t_{1}$} & \multicolumn{12}{|c|}{$\mathrm{t}_{2}$} \\
\hline & $\begin{array}{c}\text { Start } \\
\text { Benson }\end{array}$ & $\begin{array}{l}\text { Date Estimate } \\
\text { Benson }\end{array}$ & $\begin{array}{c}\text { End } \\
\text { Benson }\end{array}$ & $\begin{array}{c}\text { Start } \\
\text { Sopher }\end{array}$ & $\begin{array}{l}\text { Date Estimate } \\
\text { Sopher }\end{array}$ & $\begin{array}{l}\text { End } \\
\text { Sopher }\end{array}$ & $\begin{array}{l}\text { Start } \\
\text { Ball }\end{array}$ & $\begin{array}{l}\text { Date Estimate } \\
\text { Ball }\end{array}$ & $\begin{array}{l}\text { End } \\
\text { Ball }\end{array}$ & $\begin{array}{c}\text { Start } \\
\text { Warminster }\end{array}$ & $\begin{array}{l}\text { Date Estimate } \\
\text { Warminster }\end{array}$ & $\begin{array}{c}\text { End } \\
\text { Warminster }\end{array}$ \\
\hline Start Benson & & & & $\underline{0.53}$ & & & 0.57 & & & 0.87 & & \\
\hline Date Estimate Benson & & & & & $\underline{0.53}$ & & & $\underline{0.58}$ & & & $\underline{0.87}$ & \\
\hline End Benson & & & & & & $\underline{0.53}$ & & & $\underline{0.59}$ & & & $\underline{0.87}$ \\
\hline Start Sopher & 0.47 & & & & & & $\underline{0.53}$ & & & $\underline{0.80}$ & & \\
\hline Date Estimate Sopher & & 0.47 & & & & & & 0.53 & & & $\underline{0.79}$ & \\
\hline End Sopher & & & 0.47 & & & & & & $\underline{0.54}$ & & & 0.79 \\
\hline Start Ball & 0.43 & & & 0.47 & & & & & & 0.74 & & \\
\hline Date Estimate Ball & & 0.42 & & & 0.47 & & & & & & 0.72 & \\
\hline End Ball & & & 0.41 & & & 0.46 & & & & & & $\underline{0.70}$ \\
\hline Start Warminster & 0.13 & & & 0.20 & & & 0.26 & & & & & \\
\hline Date Estimate Warminster & & 0.13 & & & 0.21 & & & 0.28 & & & & \\
\hline End Warminster & & & 0.13 & & & 0.21 & & & 0.30 & & & \\
\hline
\end{tabular}

Note: Average of uniform probability OxCal Interval constraint models of 0-50 to 0-80 years, comparing the start and end boundaries for the OxCal Phase for each site and a site OxCal Date estimate; term $1\left(\mathrm{t}_{1}\right)$ is older than term $2\left(\mathrm{t}_{2}\right)$ when the probability is $>0.5$ (underlined) and vice versa. 
and end boundaries are known only within uncertainties, the date is a combination of the phase period and these start/end uncertainties. Overall, the OxCal Date estimate offers a good summary of the phase. The order results with interval constraints from $0-50$ to $0-90$ years are very similar; increased ambiguity and then problematic outcomes occur from the $0-100$ years to 0-120 years iterations (regarding Sopher versus Ball). However, total site durations longer than 0-50 to 0-80 years seem highly implausible (see the earlier discussion). Thus, the average order results for phase constraints of $0-50$ to 0-80 years are shown in Table 2 and form the basis for the Stage 2 sequence. The OxCal runfiles for Model 1 and Model 2 (the version with the OxCal Interval constrained to $0-80$ years) are listed in Supplemental Tables 4 and 5.

In Stage 2, we employ the likely sequence order determined in Stage 1 (comparing order probabilities for start boundaries, date estimates and end boundaries: Table 2, Supplemental Table 3), which turns out to be consistent with the assumed order from the existing ethnohistoric and archaeological assessments (in temporal order from oldest to the most recent):

1. Benson (indicated as older than all the other sites), then, after the move from such late Trent Valley sites to the early Arendarhonon sites around the beginning of the historic Wendake settlement sequence

2. Sopher (indicated as older than Ball)

3. Ball (indicated as more recent than Sopher)

4. The Warminster site (clearly more recent than all the other sites)

Whereas consistent with the ethnohistoric data, we can consider Sopher, Ball, and Warminster as after Benson, and Warminster as after Sopher and Ball, it is less clear whether we should interpret Sopher as entirely earlier than Ball or merely partly earlier and perhaps potentially partly overlapping. The order probabilities (that Sopher is older than Ball) are less than clear-cut $(p=0.53)$. We thus consider both scenarios (Models 3 and 4 with contiguous phases, and Models 5 and 6 with overlapping Sopher and Ball phases).
We may therefore create refined Bayesian chronological models for the site sequences. In the cases of Benson and Ball we also have an intrasite sequence based on archaeological assessment: some dates relate to an earlier or original core area of the site (Knight 1987; Ramsden 2009), and others relate to a subsequent later stage or expansion. We acknowledge that this is more subjective than a stratigraphic sequence. However, such likely intrasite sequences indicate some measure of additional complexity of history and duration for these settlements that provide valuable information that helps avoid overcompression of time frames. To be conservative, we consider models both with no intrasite sequence information (Models 3 and 5), and with intrasite sequences for Benson and Ball (Models 4 and 6). Once the site phases are no longer considered in isolation, there is no need to constrain site phase duration directly because the ordered sequence requires relatively short site durations: maximum site phase duration found at $95.4 \%$ probability $=67$ years; average maximum site phase duration $=35$ years at $95.4 \%$ probability and 15 years at $68.2 \%$ probability. Because it is likely that the two sites of Ball and then Warminster are successive iterations of the same community, and so the end of one site will have overlapped with the beginning of its successor, we employ trapezoidal boundaries in this instance (Lee and Bronk Ramsey 2012). The two dates identified as the larger outliers in Stage 1 are excluded in the Stage 2 models. For completeness, we include the dates run some time ago on charcoal or tree bark with the Charcoal Outlier model applied. The resulting four models (Models 3-6) covering all variations summarized are shown in full in Supplementary Figures 4-7. The OxCal runfiles for Models 3-6 are listed in Supplemental Tables 6-9.

\section{Results}

\section{Results Stage 1: Likely Site Order}

The average order probabilities from Model 2 with site phase intervals constrained between 0-50 and 0-80 years are shown in Table 2 . These indicate that Benson is likely older than 
Table 3. Modeled Calendar Age Ranges for Selected Elements from Models 3-6.

\begin{tabular}{|c|c|c|c|c|c|c|c|c|c|c|c|c|c|c|c|c|}
\hline \multirow{3}{*}{$\begin{array}{l}\text { Selected Modeled Elements } \\
\text { Boundary start Benson }\end{array}$} & \multicolumn{4}{|c|}{ Model 3} & \multicolumn{4}{|c|}{ Model 4} & \multicolumn{4}{|c|}{ Model 5} & \multicolumn{4}{|c|}{ Model 6} \\
\hline & \multicolumn{2}{|c|}{$68.2 \%$ hpd } & \multicolumn{2}{|c|}{$95.4 \%$ hpd } & \multicolumn{2}{|c|}{$68.2 \% \mathrm{hpd}$} & \multicolumn{2}{|c|}{$95.4 \%$ hpd } & \multicolumn{2}{|c|}{$68.2 \% \mathrm{hpd}$} & \multicolumn{2}{|c|}{$95.4 \%$ hpd } & \multicolumn{2}{|c|}{$68.2 \%$ hpd } & \multicolumn{2}{|c|}{$95.4 \%$ hpd } \\
\hline & 1518 & 1567 & 1511 & 1575 & 1508 & 1545 & 1490 & 1564 & 1520 & 1570 & 1506 & 1586 & 1503 & 1545 & 1483 & 1567 \\
\hline Boundary Benson early to late & & & & & 1521 & 1547 & 1517 & 1567 & & & & & 1522 & 1550 & 1517 & 1570 \\
\hline Date estimate Benson & 1523 & 1568 & 1518 & 1575 & 1519 & 1548 & 1507 & 1569 & 1525 & 1572 & 1517 & 1585 & 1519 & 1554 & 1503 & 1573 \\
\hline Interval Benson (years) & 0 & 10 & 0 & 28 & 2 & 25 & 0 & 49 & 0 & 15 & 0 & 42 & 4 & 36 & 1 & 67 \\
\hline Boundary end Benson & 527 & 1569 & 1523 & 1576 & 1528 & 1553 & 1524 & 1570 & 1545 & 1574 & 1525 & 1582 & 1532 & 1561 & 1526 & 1576 \\
\hline $\begin{array}{l}\text { Interval between Benson and Sopher } \\
\quad \text { (or Sopher and Ball) (years) }\end{array}$ & 0 & 9 & 0 & 23 & 0 & 10 & 0 & 24 & 0 & 13 & 0 & 32 & 0 & 15 & 0 & 33 \\
\hline Boundary start Sopher & 545 & 1573 & 1529 & 1583 & 1538 & 1564 & 1529 & 1576 & 1556 & 1582 & 1541 & 1592 & 1560 & 1586 & 1546 & 1592 \\
\hline Date estimate Sopher & 549 & 1575 & 1535 & 1586 & 1544 & 1569 & 1533 & 1579 & 1567 & 1590 & 1553 & 1596 & 1565 & 1589 & 1551 & 1596 \\
\hline Interval Sopher (years) & 0 & 9 & 0 & 25 & 0 & 11 & 0 & 26 & 0 & 7 & 0 & 23 & 0 & 11 & 0 & 28 \\
\hline Boundary end Sopher & 553 & 1578 & 1540 & 1590 & 1549 & 1574 & 1537 & 1584 & 1569 & 1592 & 1556 & 1599 & 1568 & 1593 & 1555 & 1601 \\
\hline Interval between Sopher and Ball (years) & 0 & 10 & 0 & 27 & 0 & 12 & 0 & 27 & & & & & & & & \\
\hline Boundary start Ball & 1559 & 1586 & 1552 & 1595 & 1557 & 1581 & 1549 & 1593 & 1559 & 1587 & 1554 & 1594 & 1557 & 1582 & 1550 & 1592 \\
\hline Boundary Ball early to late & & & & & 1569 & 1590 & 1559 & 1598 & & & & & 1563 & 1588 & 1557 & 1595 \\
\hline Date estimate Ball & 569 & 1592 & 1557 & 1600 & 1567 & 1591 & 1556 & 1601 & 1568 & 1591 & 1556 & 1596 & 1565 & 1588 & 1556 & 1597 \\
\hline Interval Ball (years) & 0 & 12 & 0 & 29 & 4 & 22 & 1 & 37 & 0 & 6 & 0 & 20 & 1 & 14 & 0 & 28 \\
\hline Boundary mid-end Ball & 1572 & 1596 & 1560 & 1605 & 1576 & 1599 & 1564 & 1607 & 1570 & 1592 & 1558 & 1598 & 1571 & 1593 & 1561 & 1601 \\
\hline Transition duration end Ball (years) & 0 & 5 & 0 & 16 & 0 & 7 & 0 & 21 & 0 & 3 & 0 & 10 & 0 & 5 & 0 & 15 \\
\hline Start end Ball & 571 & 1594 & 1558 & 1603 & 1573 & 1596 & 1560 & 1606 & 1569 & 1592 & 1558 & 1597 & 1569 & 1592 & 1559 & 1599 \\
\hline End-end Ball & 1573 & 1597 & 1561 & 1608 & 1579 & 1602 & 1566 & 1611 & 1571 & 1593 & 1558 & 1600 & 1573 & 1595 & 1562 & 1604 \\
\hline Boundary mid-start Warminster & 1577 & 1614 & 1569 & 1621 & 1589 & 1616 & 1575 & 1622 & 1574 & 1599 & 1565 & 1614 & 1581 & 1608 & 1570 & 1617 \\
\hline Transition duration start Warminster (years) & 0 & 5 & 0 & 16 & 0 & 6 & 0 & 18 & 0 & 6 & 0 & 19 & 0 & 8 & 0 & 22 \\
\hline Start-start Warminster & 1576 & 1610 & 1568 & 1619 & 1587 & 1613 & 1573 & 1620 & 1573 & 1597 & 1560 & 1609 & 1576 & 1601 & 1567 & 1613 \\
\hline End start Warminster & 1577 & 1617 & 1570 & 1625 & 1590 & 1619 & 1577 & 1627 & 1575 & 1601 & 1560 & 1620 & 1584 & 1612 & 1571 & 1623 \\
\hline Date estimate Warminster & 1578 & 1620 & 1572 & 1629 & 1592 & 1622 & 1578 & 1631 & 1575 & 1606 & 1561 & 1628 & 1589 & 1619 & 1574 & 1630 \\
\hline Interval Warminster (years) & 0 & 12 & 0 & 30 & 1 & 15 & 0 & 33 & 0 & 18 & 0 & 44 & 1 & 23 & 0 & 46 \\
\hline Boundary end Warminster & 1579 & 1628 & 1573 & 1637 & 1596 & 1630 & 1580 & 1639 & 1578 & 1623 & 1562 & 1641 & 1596 & 1629 & 1578 & 1642 \\
\hline
\end{tabular}




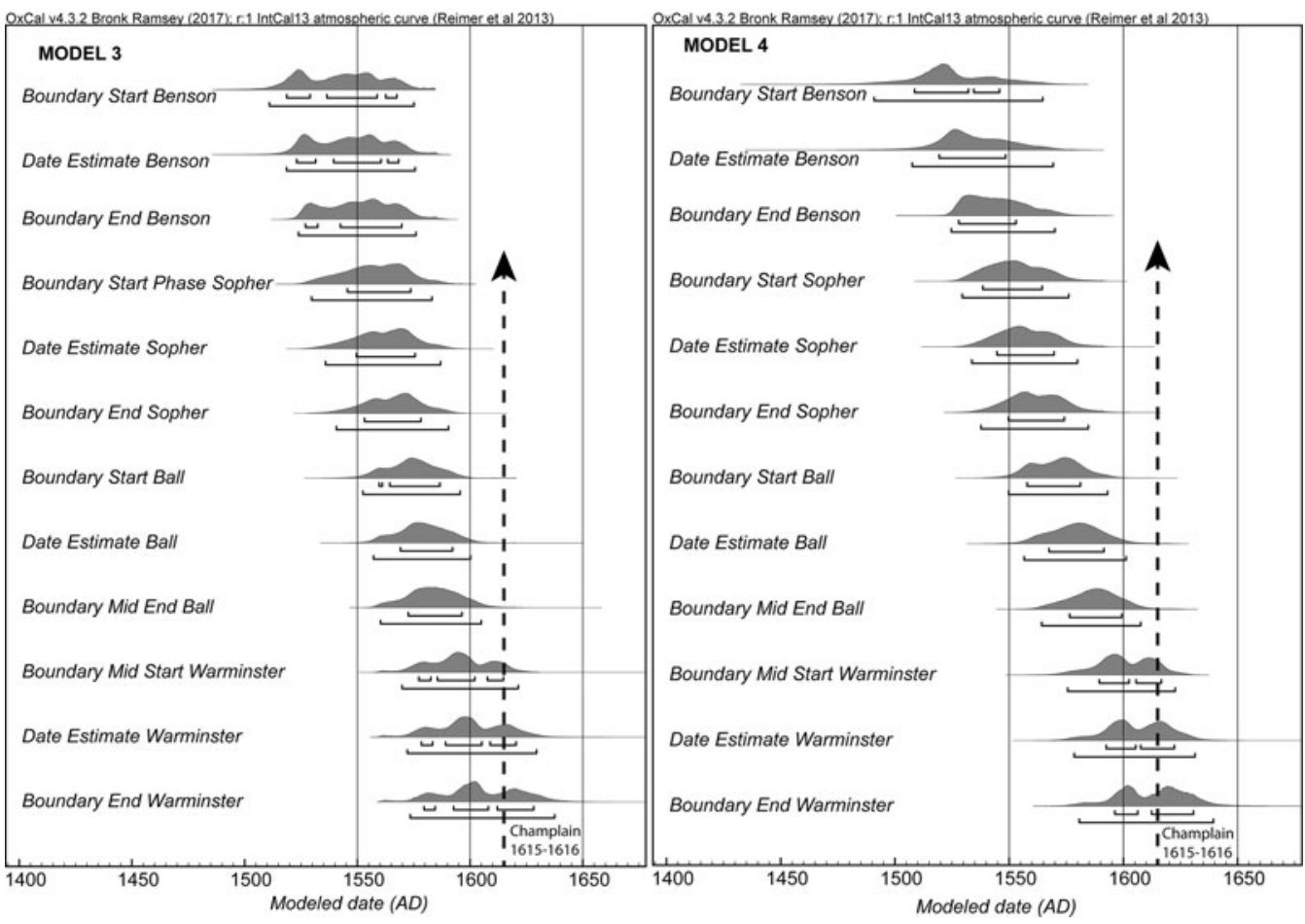

Figure 5. Details of start and end boundaries and date estimates for the Benson, Sopher, Ball, and Warminster site phases from Models 3 and 4 (contiguous sequences of 1. Benson, then 2. Sopher, then 3. Ball. then 4. Warminster, with Model 4 including the intraphase sequences for Benson and Ball). The 1615-1616 period when Samuel de Champlain was at Cahiagué is indicated in each case. Data from OxCal 4.3.2 (Bronk Ramsey 2009a; 2009b) and IntCal13 (Reimer et al. 2013) with curve resolution set at one year. For the full results of Models 3 and 4, see Supplemental Figures 4-5.

all the other sites and that Warminster is likely more recent than all the other sites. Sopher is indicated as slightly older than Ball, but may well partly overlap.

\section{Results Stage 2: Site Sequence}

Models 3-6 incorporate the order identified in Stage 1 and the variations of (1) whether to include the intrasite sequences for Benson and Ball and (2) whether to treat Sopher as earlier than Ball or as potentially overlapping with Ball (see the earlier discussion). Details of the four models are shown in Supplemental Figures 4-7. Selected elements (start and end boundaries and date estimates for each site phase) are listed in Table 3 and shown in Figures 5 and 6 where they are also compared with the 1615-1616 date for Champlain's visit at Cahiagué. It is evident that only the Warminster site is potentially compatible. The likely interval of time between the Benson site and the Sopher or Sopher and Ball sites is relatively short (maximum of $0-15$ years at $68.2 \% \mathrm{hpd}, 0-33$ years at $95.4 \% \mathrm{hpd}$ across the four models). The site occupations of Benson, and then one or both of Sopher and Ball, could therefore be approximately contiguous, or there could be an intervening site locus/loci in the Arendarhonon sequence. Only two dates are potentially very minor outliers (at the 6-8\% level, varying by model and run): GrM-17562 and VERA-6282_2. Otherwise, the four models have satisfactory Amodel and Aoverall values and offer broadly similar results: Sopher necessarily dates earlier in the contiguous sequence Models 3 and 4.

The relevance of the intrasite sequences recognized archaeologically at Benson and Ball 

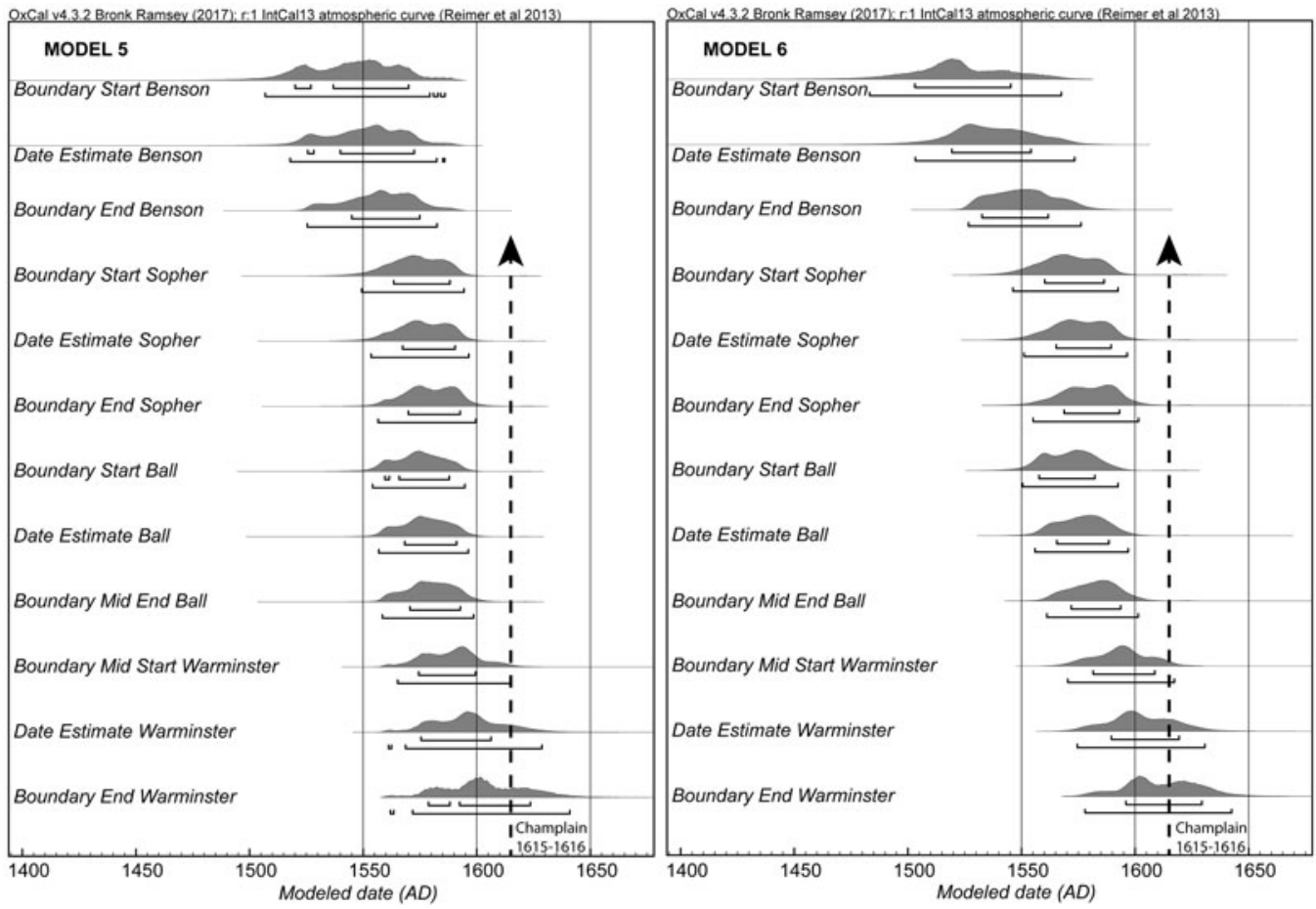

Figure 6. Details of start and end boundaries and date estimates for the Benson, Sopher, Ball, and Warminster site phases from Models 5 and 6 (sequences of 1. Benson, then 2. Sopher \& Ball in a phase, and then 3. Warminster, with Model 6 including the intraphase sequences for Benson and Ball). The 1615-1616 period when Samuel de Champlain was at Cahiagué is indicated in each case. Data from OxCal 4.3.2 (Bronk Ramsey 2009a; 2009b) and IntCal13 (Reimer et al. 2013) with curve resolution set at one year. For the full results of Models 5 and 6, see Supplemental Figures 6-7.

is evident. Such information helps mitigate against overcompression of the site durations. It is notable that the one model in which the $68.2 \%$ hpd date estimate for Warminster does not include Champlain's visit is one of the two models not employing the intrasite sequences (Model 5). We regard the models allowing for the internal sequences at Benson and Ball as most likely yielding our best age estimates (Models 4 and 6). The $68.2 \%$ and $95.4 \%$ hpd results from Models 4 and 6 are compared to some previous date estimates for the four sites in Figure 7 to illustrate the changes found.

\section{Discussion}

The available independent radiocarbon data indicate that the Warminster site was very likely occupied in the period 1615-1616 when
Champlain overwintered in the principal town of the Arendarhonon nation. In contrast, the other sometimes proposed candidate, the Ball site, likely dates earlier, with the end of the Ball site phase boundary no later than cal AD 15981607 even at $95.4 \%$ probability (Table 2 ). This conclusion in terms of both the order of the sites and the date ranges is supported both independently from the radiocarbon analysis and from the existing archaeohistoric assessment. Warminster is therefore the current best (indeed only) candidate for Cahiagué of those sites proposed. This largely resolves previous hypotheses and debate. Our modeled age estimates further indicate that Champlain's visit occurred likely toward the later part of the village's overall occupation period and consistent with the stratigraphic associations of trade goods (McIlwraith 1947). When these results are considered in light of Sagard's statement- that the village was reduced 


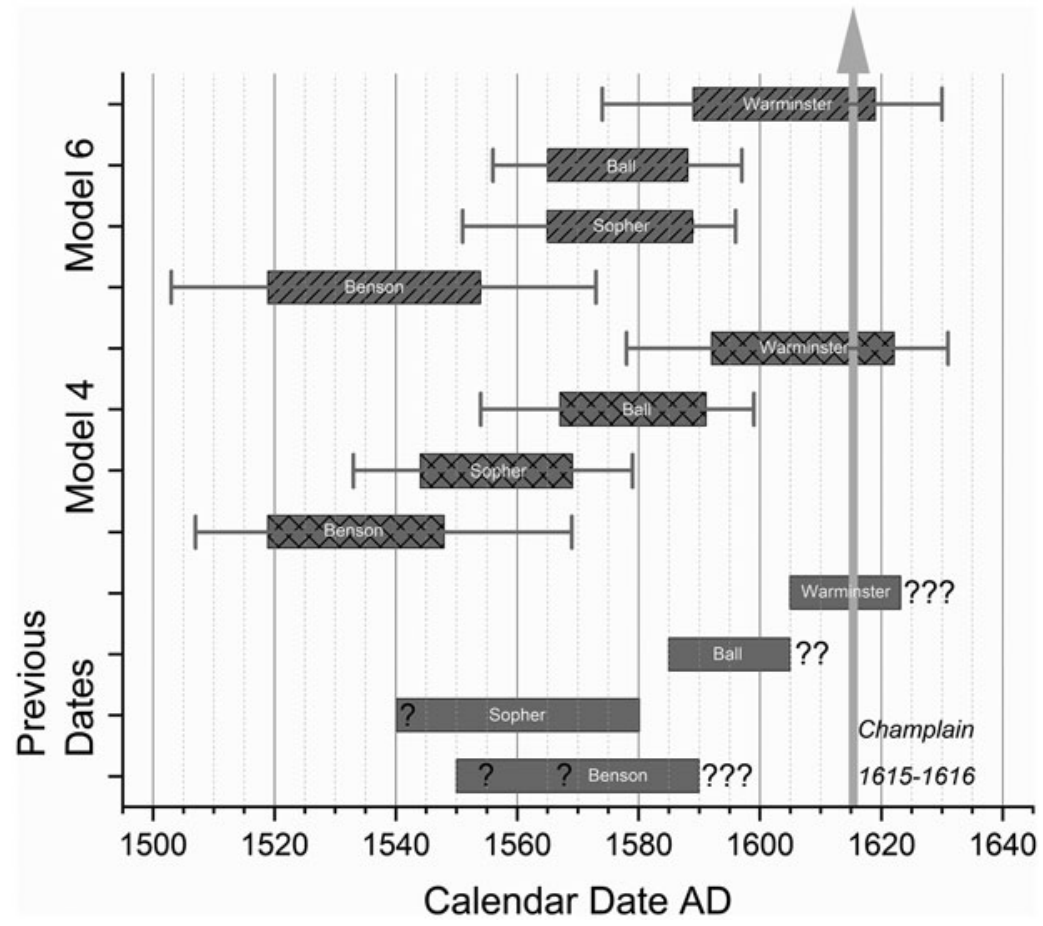

Figure 7. Comparison of some existing date estimates for the Benson, Sopher, Ball, and Warminster sites (Ramsden 2016a, 2016b; Warrick 2008) with the 68.2\% hpd ranges from Models 4 and 6 as boxes and the $95.4 \%$ ranges indicated by the error bars around these (data from Table 2) and with the 1615-1616 date for Champlain's visit to Cahiagué. Question marks indicate the direction of movement or uncertainty versus some other date estimations in the literature (e.g., Fitzgerald 1986, 1990; Fitzgerald et al. 1995; Noble 1971; Ramsden 2016a, 2016b).

in size, divided in two, and rebuilt some distance away ca. 1624-we might infer that this process of separation and relocation refers to processes that took place late in the Warminster site's occupation. As such, the statement refers to Cahiagué's relocation and not its founding.

The Benson-Sopher-Ball-Warminster sequence and dates and other work on the West Duffins sequence comprising the Draper, Spang, and Jean-Baptiste Lainé (Mantle) sites and dates (Manning et al. 2018) begin to open a new window onto a widespread reconsideration of previous archaeological synthesis and the potential resolution of past challenges. One example is the now venerable archaeometric study of Trigger and colleagues (1980) on a set of Iroquoian ceramics. Trigger and colleagues found what was-given the then-conventional chronology - a problem (see also the summary in Garrad 2014:290). Trace elements in the clays from ceramics found at the Sidey-Mackey site, a large late sixteenth-century village, linked Sidey-Mackey to the Draper site, and Draper to Benson, implying that part of the Draper population resettled at Sidey-Mackey, Benson, or both. But this seemed impossible given the thenconventional chronology, which assumed that Draper dated to as much as a century earlier than both Sidey-Mackey and Benson. However, the new radiocarbon time frame changes this picture, providing similar earlier to mid-sixteenthcentury redatings for both Draper (cal AD 1528-1544 68.2\% hpd and 1523-1555 95.4\% hpd; Manning et al. 2018:Figure 4 model) and, very slightly later, Benson (within cal $\mathrm{AD}$ 1519-1572 68.2\% hpd and 1507-1585 95.4\% hpd: Table 2). Thus, the ceramic-informed scenario found in the analysis of Trigger and colleagues (1980) now appears quite plausible, given the radiocarbon evidence.

Regarding implications for trade good chronologies, the independent dating of sites in this 
study and in our previous work (Manning et al. 2018) has shown that we have reason to question foundational assumptions about the timing of site occupations based primarily on trade good data, which assume that similarly dated sites will have similar assemblages of European trade goods. For example, the recognition that the Draper and Benson sites, and the JeanBaptiste Lainé (Mantle) and Warminster sites were at least partly contemporary with one another is at odds with assumptions derived from the glass bead chronology. No trade goods were identified at Draper, whereas Benson has what would be considered a GBP1 assemblage, Jean-Baptiste Lainé (Mantle) has what would be considered a GBP1 assemblage, and Warminster has what has been considered a GBP2 assemblage. With AMS radiocarbon dates as the primary temporal referent for these sites, we can consider the variation in European trade good assemblages among them as a factor of various social, political, and economic processes. The differential distribution of trade goods on late sixteenth- and early seventeenthcentury sites may have been related to a variety of factors including, but not limited to, differential participation in exchange networks, geopolitical maneuvering, differences between mortuary and residential site assemblages, taphonomic processes, or investigation methods. Our results demonstrate that the comparison of chronological assessments derived from independent methods such as radiocarbon analyses and trade good distributions warrants further attention from researchers.

The Arendarhonon are noted in the ethnohistoric literature as being the first Wendat group to encounter the French and, in keeping with Wendat custom, gained the privilege of being the sole traders (Thwaites 1896-1901:10:225, 20:19). Although they were initially kinship based, early proprietary trading rights gave way to more extensive distribution as the volume of material increased, and the Huron-Wendat entered more fully into the expanding European world-system, as demonstrated by geochemical characterization of copper from early versus later contact period contexts (Pavlish et al. 2018). The timing and tempo of this process and its variation between different Wendat communities are just several of the questions for which a refined absolute time frame for contact-era sites, as discussed here, would enable meaningful investigation.

The utility of radiocarbon dates in Iroquoian archaeology has at times been questioned based on the short durations of site occupation and the previously large uncertainties in radiocarbon age determinations. This is especially the case for the later precontact and early contact period (middle to late 1500 s through the early 1600s) because of the shape of the radiocarbon calibration curve that spreads out possible date ranges in the absence of constraints (Figure 3). In previous decades, the discrepancies between often imprecise and ambiguous radiocarbon-based dates and those from assessments derived from ethnohistoric and trade goods analysis, and the extrapolation of these via ceramic serialization, created problems and often a wider perception that the radiocarbon analysis was less than helpful. The situation is now fundamentally changed. The combination of high-resolution AMS radiocarbon dating on carefully selected samples directly associated with the archaeological contexts of interest with the application of Bayesian chronological modeling permits a new tight, absolute chronological control and the building of local to regional time frames. Where available, even short dendrochronological sequences for ${ }^{14} \mathrm{C}$ wiggle matching can provide key constraints. The Warminster case investigated in this article demonstrates the ability to date closely a site and to test (and likely confirm) a specific historical association (Champlain in 1615-1616; Figures 5 and 6). The analysis of the Benson-Sopher-Ball-Warminster site sequence demonstrates an ability to resolve and date sites and likely occupation spans at close to an historical-level scale (around decadal-level resolution), as does the West Duffins case (Manning et al. 2018).

Our research agenda should now move forward, given the ability to achieve high-resolution calendar age estimates matching the relatively short life-spans of Iroquoian sites. Targeted radiocarbon dating of suitable samples from secure archaeological contexts should therefore be an objective of modern research agendas in the Northeast. These steps should be undertaken 
even in cases where trade good chronologies and ethnohistoric accounts point to possible links between the archaeological and historic records. Such independent age verification can help resolve ambiguities in these accounts and usefully test hypotheses based on qualitative data.

Acknowledgments. At the University of Toronto, St. George Campus, we thank Kathryn David for her assistance with access to and information on the post from Feature 13 and the seed samples, and Ted Banning for his permission. We thank William Fox for sharing his recollections of the Warminster excavations. Thanks to Trevor Orchard for facilitating access to the Ball site collections curated at the University of Toronto, Mississauga Campus. We thank Peter Ramsden for providing the Benson samples. We also thank Eva Maria Wild and the VERA Laboratory, University of Vienna; Alan Hogg and the University of Waikato Radiocarbon Laboratory; the Center for Isotope Research, University of Groningen; and the Center for Applied Isotope Studies, University of Georgia. We acknowledge support from the National Science Foundation award BCS 1727802 and thank our Dating Iroquoia collaborator Samantha Sanft. Support was also received from the Department of Classics and College of Arts \& Sciences at Cornell University and the Office of the Vice President for Research, the Graduate School, and the Center for Archaeological Sciences at the University of Georgia.

Data Availability Statement. All data used in this paper are available from the text and supplemental materials. The radiocarbon dates used are listed in Table 1. The OxCal runfiles for the models are provided in Supplemental Tables 4-9.

Supplementary Materials. For supplementary material accompanying this article, visit https://doi.org/10.1017/aaq. 2019.60

Supplemental Text File. Supplemental Figure Captions.

Supplemental Figure 1. The wiggle-match placement of the Feature 13 wood post, WAR-1, from Warminster.

Supplemental Figure 2. Model 1.

Supplemental Figure 3. The interval query results for the durations of each site phase in Model 1.

Supplemental Figure 4. Example Model 3 results.

Supplemental Figure 5. Example Model 4 results.

Supplemental Figure 6. Example Model 5 results.

Supplemental Figure 7. Example Model 6 results.

Supplemental Table 1. Individual Nonmodeled Calibrated

Calendar Age Ranges for the Radiocarbon Dates in Table 1.

Supplemental Table 2. Order Analysis from Model 1.

Supplemental Table 3. Order Analysis from Model 2.

Supplemental Table 4. OxCal Runfile for Model 1.

Supplemental Table 5. OxCal Runfile for Model 2.

Supplemental Table 6. OxCal Runfile for Model 3.

Supplemental Table 7. OxCal Runfile for Model 4.
Supplemental Table 8. OxCal Runfile for Model 5.

Supplemental Table 9. OxCal Runfile for Model 6.

\section{References Cited}

Bayliss, Alex

2009 Rolling Out Revolution: Using Radiocarbon Dating in Archaeology. Radiocarbon 51:123-147.

2015 Quality in Bayesian Chronological Models in Archaeology. World Archaeology 47:677-700.

Biggar, Henry Percival (editor)

1922-1936 The Works of Samuel de Champlain. 6 vols. Translated by H. H. Langton and W. F. Ganong. Champlain Society, Toronto. Reprinted in 1971, University of Toronto Press, Toronto.

Birch, Jennifer

2015 Current Research on the Historical Development of Northern Iroquoian Societies. Journal of Archaeological Research 23:263-323.

Birch, Jennifer, and Ronald F. Williamson

2013 The Mantle Site: An Archaeological History of an Ancestral Wendat Community. AltaMira, Lanham, Maryland.

Bonneau, Adelphine, Jean-François Moreau, Ron G. V. Hancock, and Karlis Karklins

2013 Archaeometrical Analysis of Glass Beads: Potential, Limitations, and Results. BEADS: Journal of the Society of Bead Researchers 26:35-46.

Bradley, James W.

2007 Before Albany. New York State Museum Bulletin 509. New York State Education Department, Albany.

Bronk Ramsey, Christopher

2009a Bayesian Analysis of Radiocarbon Dates. Radiocarbon 51:337-360.

2009b Dealing with Outliers and Offsets in Radiocarbon Dating. Radiocarbon 51:1023-1045.

Bronk Ramsey, Christopher, Johannes van der Plicht, and Bernhard Weninger

2001 “Wiggle Matching” Radiocarbon Dates. Radiocarbon 43:381-389.

Buck, Caitlin E., James B. Kenworthy, Cliff D. Litton, and Adrian F. M. Smith

1991 Combining Archaeological and Radiocarbon Information: A Bayesian Approach to Calibration. Antiquity 65:808-821.

Buckley, James

1976 Isotopes' Radiocarbon Measurements XI. Radiocarbon 18:172-189.

Cherkinsky Alexander, Randy A. Culp, Doug K. Dvoracek, and John E. Noakes

2010 Status of the AMS Facility at the Center for Applied Isotope Studies, University of Georgia. Nuclear Instruments and Methods in Physics Research B 268:867-870.

Fitzgerald, William R.

1986 Is the Warminster Site Champlain's Cahiagué? Ontario Archaeology 45:3-7.

1990 Chronology to Cultural Process: Lower Great Lakes Archaeology, 1500-1650. PhD dissertation, Department of Anthropology, McGill University, Montreal.eScholarship@McGill, http://digitool.library.mcgill.ca/R/?func= dbin-jump-full\&object_id=39234\&local_base=GEN01MCG02. 
Fitzgerald, William R., Dean H. Knight, and Allison Bain 1995 Untanglers of Matters Temporal and Cultural: Glass Beads and the Early Contact Period Huron Ball site. Canadian Journal of Archaeology 19:117-138.

Fitzgerald, William R., Laurier Turgeon, Ruth Holmes Whitehead, and James W. Bradley

1993 Late Sixteenth-Century Basque Banded Copper Kettles. Historical Archaeology 27(1):44-57.

Fogt, Lisa, and Peter Ramsden

1996 From Timepiece to Time Machine: Scale and Complexity in Iroquoian Archaeology. In Debating Complexity: Proceedings of the 26th Annual Chacmool Conference, edited by Donald T. Hanna, Daniel A. Meyer, and Peter C. Dawson, pp. 39-45. Archaeological Association of the University of Calgary, Calgary.

Galimberti, Mariagrazia, Christopher Bronk Ramsey, and Sturt W. Manning

2004 Wiggle-Match Dating of Tree-Ring Sequences. Radiocarbon 46:917-924.

Garrad, Charles

2014 Petun to Wyandot: The Ontario Petun from the Sixteenth Century. Edited by Jean-Luc Pilon and William Fox. University of Ottawa Press, Gatineau.

Hamilton, W. Derek, and Anthony M. Krus

2018 The Myths and Realities of Bayesian Chronological Modeling Revealed. American Antiquity 83:187-203.

Hancock, Ronald G. V.

2012 European Glass Trade Beads in Northeastern North America. In Modern Methods for Analyzing Archaeological and Historical Glass, edited by Koen Janssens, pp. 457-469. John Wiley \& Sons, New York.

Hancock, Ronald G. V., J. McKechnie, Susan Aufreiter, Karlis Karklins, M. Kapches, M. Sempowski, J.- F. Moreau, and Ian Kenyon

2000 Non-Destructive Analysis of European Cobalt Blue Glass Trade Beads. Journal of Radioanalytical and Nuclear Chemistry 244:567-573.

Heidenreich, Conrad E.

1971 Huronia: A History and Geography of the Huron Indians, 1600-1650. McLelland and Stewart, Toronto.

2014 Samuel de Champlain in Wendake: The Country of the Huron in Ontario, 1615-1616. Oak Cottage Productions, DeGrassi Point, Ontario.

Higham, Tom, Katerina Douka, Rachel Wood, Christopher Bronk Ramsey, Fiona Brock, Laura Basell, Marta Camps, Alvaro Arrizabalaga, Javier Baena, Cecillio Barroso-Ruíz, Christopher Bergman, Coralie Boitard, Paolo Boscato, Miguel Caparrós, Nicholas J. Conard, Christelle Draily, Alain Froment, Bertila Galván, Paolo Gambassini, Alejandro Garcia-Moreno, Stefano Grimaldi, Paul Haesaerts, Brigitte Holt, Maria-Jose IriarteChiapusso, Arthur Jelinek, Jesús F. Jordá Pardo, JoséManuel Maíllo-Fernández, Anat Marom, Julià Maroto, Mario Menéndez, Laure Metz, Eugène Morin, Adriana Moroni, Fabio Negrino, Eleni Panagopoulou, Marco Peresani, Stéphane Pirson, Marco de la Rasilla, Julien RielSalvatore, Annamaria Ronchitelli, David Santamaria, Patrick Semal, Ludovic Slimak, Joaquim Soler, Narcís Soler, Aritza Villaluenga, Ron Pinhasi, and Roger Jacobi

2014 The Timing and Spatiotemporal Patterning of Neanderthal Disappearance. Nature 512:306-309.

Hunter, Andrew

1902 Notes on Sites of Huron Villages in the Township of Medonte (Simcoe County). In Annual Archaeological Report for 1901 to the Report of the Minister of
Education for Ontario, pp. 56-100. Warwick Bros \& Rutter, Toronto.

Jones, Travis, Jennifer Birch, Ronald F. Williamson, Timothy J. Abel, Robert J. Speakman, and Louis Lesage

2018 Steatite Characterization Using X-Ray Fluorescence and Insights into Northern Iroquoian Interregional Interaction. Journal of Archaeological Science: Reports 20:506-515.

Kenyon, Ian T., and William R. Fitzgerald

1986 Dutch Glass Beads in the Northeast: An Ontario Perspective. Man in the Northeast 32:1-34.

Kenyon, Ian T., and Thomas A. Kenyon

1983 Comments on 17th Century Glass Trade Beads from Ontario. In Proceedings of the 1982 Glass Trade Bead Conference, edited by Charles F. Hayes III, pp. 59-74. Research Records No. 16. Rochester Museum \& Science Center, Rochester, New York.

Knight, Dean

1987 Settlement Patterns at the Ball Site: A 17th Century Huron Village. Archaeology of Eastern North America 15:177-188.

Lee, Sharen, and Christopher Bronk Ramsey

2012 Development and Application of the Trapezoidal Model for Archaeological Chronologies. Radiocarbon 54:107-122.

Loewen, Brad

2016 Sixteenth-Century Beads: New Data, New Directions. In Contact in the 16th Century: Networks among Fishers, Foragers, and Farmers, edited by Brad Loewen and Claude Chapdelaine, pp. 269-286. Canadian Museum of History and University of Ottawa Press, Ottawa.

McIlwraith, Thomas F.

1946 Archaeological Work in Huronia, 1946: Excavations Near Warminster. Canadian Historical Review 27:394 401.

1947 On the Location of Cahiagué. Transactions of the Royal Society of Canada 4:99-102.

Manning, Sturt W., Jennifer Birch, Megan Anne Conger, Michael W. Dee, Carol Griggs, Carla S. Hadden, Alan G. Hogg, Christopher Bronk Ramsey, Samantha Sanft, Peter Steier, and Eva M. Wild

2018 Radiocarbon Re-Dating of Contact Era Iroquoian History in Northeastern North America. Science Advances 4(12):eaav0280. DOI:10.1126/sciadv.aav0280.

Manning, Sturt W., Christopher Bronk Ramsey, Walter Kutschera, Thomas Higham, Bernd Kromer, Peter Steier, and Eva M. Wild

2006 Chronology for the Aegean Late Bronze Age 17001400 B.C. Science 312:565-569.

Martelle, Holly

2002 Huron Potters and Archaeological Constructs: Researching Ceramic Micro-Stylistics. PhD dissertation, Department of Anthropology, University of Toronto, Toronto. Collections Canada. http://www.collectionsca nada.gc.ca/obj/s4/f2/dsk4/etd/NQ69090.PDF.

Michelaki, Kostalena, Ronald G. V. Hancock, Gary Warrick, and Dean Knight

2013 17th Century Huron Village Life: Insights from the Copper-Based Metals of the Ball Site, Southern Ontario, Canada. Journal of Archaeological Science 40:1250 1259.

Noble, William C.

1968 Iroquois Archaeology and the Development of Iroquois Social Organization (1000-650 AD): A Study in Culture Change Based on Archaeology, Ethnohistory, 
and Ethnology. $\mathrm{PhD}$ dissertation, Department of Archaeology, University of Calgary, Calgary, Alberta. PRISM. http://hdl.handle.net/1880/2133.

1971 The Sopher Celt: An Indicator of Early Protohistoric Trade in Huronia. Ontario Archaeology 16:42-48.

Pavlish, Lawrence A., Kostalena Michelaki, Jean-Francois Moreau, Ron M. Farquhar, William Fox, Lisa M. Anselmi, Charles Garrad, C. Walker, Gary Warrick, Dean Knight, and Suzanne Aufreiter

2018 Tracing the Distribution of Late 16th and Early 17th Century European Copper Artefacts in Southern Québec and Ontario, Canada. Archaeometry 60:517-534.

Ramsden, Peter G.

1978 Late Iroquoian Occupations of South-Central Ontario: A Preliminary Report on the 1977 Field Season. Manuscript submitted to the Canada Council.

1988 Palisade Extension, Village Expansion, and Immigration in Iroquoian Sites in the Upper Trent Valley. Canadian Journal of Archaeology 12:177-183.

1990 Saint Lawrence Iroquoians in the Upper Trent River Valley. Man in the Northeast 39:87-95.

2009 Politics in a Huron Village. In Painting the Past with a Broad Brush: Papers in Honor of James Valliere Wright, edited by David L. Keenleyside and Jean-Luc Pilon, pp. 299-318. Archaeological Survey of Canada. Mercury Series Paper No. 170. Canadian Museum of Civilization, Gatineau.

2016a Becoming Wendat: Negotiating a New Identity around Balsam Lake in the Late Sixteenth Century. Ontario Archaeology 96:121-132.

2016b Sixteenth-Century Contact between the Saint Lawrence Valley and the Upper Trent Valley. In Contact in the 16th Century: Networks among Foragers, Fishers, and Farmers, edited by Brad Loewen and Claude Chapdelaine, pp. 219-234. Canadian Museum of History and University of Ottawa Press, Gatineau.

Reimer, Paula, Edouard Bard, Alex Bayliss, J Warren Beck, Paul G. Blackwell, Christopher Bronk Ramsey, Caitlin E. Buck, Hai Cheng, R. Lawrence Edwards, Michael Friedrich, Pieter M. Grootes, Thomas P. Guilderson, Haflidi Haflidason, Irka Hajdas, Christine Hatté, Timothy J. Heaton, Dirk L. Hoffman, Alan G. Hogg, Konrad A. Hughen, K. Felix Kaiser, Bernd Kromer, Sturt W. Manning, Mu Niu, Ron W. Reimer, David A. Richards, E. Marian Scott, John R. Southon, Richard A. Staff, Christian S. M. Turney, and Johannes van der Plicht

2013 IntCal13 and Marine13 Radiocarbon Age Calibration Curves 0-50,000 Years cal BP. Radiocarbon 55:1869-1887.

Rutherford, A. A., Juergen Wittenberg, and Roscoe Wilmeth 1981 University of Saskatchewan Dates IX. Radiocarbon 23:94-135.

Steckley, John L.

2007 Words of the Huron. Wilfrid Laurier University Press, Waterloo, Ontario, Canada.

2009 Gabriel Sagard's Dictionary of Huron. ALR Supplement Series Vol. 2. Evolution Publishing, Merchantville, New Jersey.
Stuiver, Minze, and Thomas F. Braziunas

1998 Anthropogenic and Solar Components of Hemispheric ${ }^{14}$ C. Geophysical Research Letters 25:329-332.

Sykes, Clark M.

1980 Swidden Horticulture and Iroquoian Settlement. Archaeology of Eastern North America 8:45-52.

1983 An Archaeological and Ethnohistorical Analysis of Huron Intra-Community Exchange Systems. PhD dissertation, Department of Anthropology, University of Toronto, Toronto.

Thompson, Victor D., Richard W. Jeffries, and Christopher R. Moore

2019 The Case for Radiocarbon Dating and Bayesian Analysis in Historical Archaeology. Historical Archaeology 53:181-192.

Thwaites, Reuben Gold

1896-1901 The Jesuit Relations and Allied Documents. 73 vols. Burrows Brothers, Cleveland, Ohio.

Tooker, Elizabeth

1964 An Ethnography of the Huron Indians, 1615-1649. Bureau of American Ethnology Bulletin 190. Smithsonian Institution, Washington, DC

Trigger, Bruce $\mathrm{G}$.

1969 The Huron: Farmers of the North. Holt, Rinehart, and Winston, New York.

1976 The Children of Aataentsic: A History of the Huron People to 1660. 2 vols. McGill-Queen's University Press, Kingston, Ontario, Canada.

Trigger, Bruce G., L. Yaffe, M. Diksic, J.-L. Galinier, H. Marshall, and James F. Pendergast

1980 Trace-Element Analysis of Iroquoian Pottery. Canadian Journal of Archaeology 4:199-145.

Walder, Heather

2013 Stylistic and Chemical Investigation of TurquoiseBlue Glass Artifacts from the Contact Era of Wisconsin Midcontinental Journal of Archaeology 38:119-142.

Ward, Graeme K., and Susan R. Wilson

1978 Procedures for Comparing and Combining Radiocarbon Age Determinations: A Critique. Archaeometry 20:19-31.

Warrick, Gary A.

1988 Estimating Ontario Iroquoian Village Duration. Man in the Northeast 36:21-60.

2008 A Population History of the Huron-Petun, A.D. 500 1650. Cambridge University Press, New York

Whittle, Alisdair, Fances Healy, and Alex Bayliss

2011 Gathering Time: Dating the Early Neolithic Enclosures of Southern Britain and Ireland. Oxbow Books, Oxford.

Williamson, Ronald F.

2014 The Archaeological History of the Wendat to A.D. 1651: An Overview. Ontario Archaeology 94:3-63.

Wrong, George M. (editor)

1939 Sagard's Long Journey to the Country of the Hurons [1632]. Champlain Society, Toronto.

Submitted November 6, 2018; Revised May 8, 2019;

Accepted May 9, 2019 